\title{
Black Africans' Freedom Litigation Suits to Define Just War and Just Slavery in the Early Spanish Empire
}

\author{
CHLOE L. IRETON, University College London
}

This article explores how some enslaved Black Africans litigated for their freedom in Spanish royal courts in the sixteenth century on the basis that — as Christians — they had been unjustly enslaved in Africa. With a focus on the port cities of Seville and Cartagena, I explore how freedom litigation suits illuminate how individuals from starkly different social worlds and intellectual milieus-who inhabited the same urban sites—affected and shaped one another's intellectual landscapes. I trace how enslaved Africans' epistemologies of just slavery shaped broader discourses on the just enslavement of Africans in the Spanish Empire.

\section{INTRODUCTION}

THIS ARTICLE TRACES enslaved Africans' epistemologies of just and unjust slavery in the sixteenth- and seventeenth-century Spanish Atlantic and explores how they shaped broader legal discourses regarding the illegitimacy of enslaving Africans. I explore an intellectual history of discourses of just and unjust slavery among enslaved Guineans in the early Iberian Atlantic by mining legal petitions for freedom in Castilian royal courts spearheaded by enslaved Black Guineans on the basis that their enslavement in Guinea had been illegitimate. I trace how theologians and enslaved Guineans in Iberian port cities of the sixteenth and early seventeenth centuries drew on shared understandings of an Iberian legal definition of just war that permitted the enslavement of non-Christians.

This article is dedicated to Jorge Cañizares-Esguerra for his solidarity, mentorship, friendship, and unwavering commitment to ensuring that diverse voices enter and remain in the historical profession. I also thank Susan Deans-Smith, Nelson Fernando González Martínez, Martin van Gelderen, Julie Hardwick, Tamar Herzog, Mark Hutchinson, Matthew Kruer, Aishwary Kumar, Jane Landers, Paul Lovejoy, Giuseppe Marcocci, Adrian Masters, Rachel Sarah O’Toole, Brian Owensby, Richard Ross, Erin Rowe, Andres Vélez Posada, the anonymous $R Q$ reviewers, and the Leverhulme Trust.

Renaissance Quarterly (2020): 1-43 (C) Renaissance Society of America 2020.

doi: $10.1017 /$ rqx.2020.219 
In doing so, they created competing stereotyped representations of Africa in order to debate the legitimacy of the enslavement of Africans. These reductive representations dichotomously painted Africa as either pagan or Christian, often without any consideration for the varied and syncretic forms of Christianity that existed across various regions in Upper Guinea and WestCentral Africa. ${ }^{1}$ The article traces how some enslaved Black Guineans litigated for their freedom in Spanish royal courts in the sixteenth and early seventeenth century on the basis that-as Christians - they had been unjustly enslaved in Africa. These freedom litigation suits illuminate how enslaved Black Guineans spearheaded broader transatlantic discourses that sought to place limits on the legality and justifications of slavery. This exploration of enslaved Africans' impact on the discursive landscapes of the Iberian cities where they resided goes some way to position Black Africans as important actors in the intellectual history of the Atlantic world, in this particular case, within discourses of just and unjust slavery and the discursive landscapes of the various locales where they lived.

With a focus on two port cities of the early Spanish Empire-where discourses on just war for slavery became acute-I examine how theologians and Africans in these sites deployed conflicting representations of a Christian Africa to shape ideas about just slavery in the Spanish Empire. First, I explore how early to mid-sixteenth-century Seville became the site of pronounced debates about just war with regard to the enslavement of Indigenous Americans, which also extended to discussions about the legitimacy of African slavery. Seville-based Dominican friar Bartolomé de Las Casas (1474-1566), who spearheaded a successful antislavery discourse with regard to Indigenous slavery, eventually also condemned the enslavement of Africans by arguing that all Africans were pagans. ${ }^{2}$ By the mid-sixteenth century, Las Casas argued that the enslavement of Africans was unjust, because, like Indigenous Americans, they had not been exposed to Christianity. On the other hand, arguing for the existence of Christian regions in Africa allowed for enslaved West Africans to contest slaveholders' narratives in royal courts in the Spanish Empire. Slaveholders would argue for the just enslavement of their captives on the basis that such Africans had been rescatados (ransomed) or captured in a just war, while Africans litigating for their freedom argued that they had been illegitimately abducted. Presenting Africa as Christian allowed for enslaved Africans to document that they did not fall within either of the two

\footnotetext{
${ }^{1}$ Fromont, 1-20; Havik, 2009; Heywood and Thornton, 49-108; Thornton, 1984 and 2013.

${ }^{2}$ Camplani; Las Casas, 253-56; Sánchez-Godoy, 2011 and 2016.
} 
categories that would justify their enslavement (just war and rescate), as they argued that they were Christians. ${ }^{3}$

Next, the article transitions temporally and geographically across the Atlantic Ocean to the port city of Cartagena de Indias in the early decades of the seventeenth century. By then one of the highest-volume slave-trading ports of the Spanish Atlantic, Cartagena became the site of pronounced debates regarding the legitimacy of enslaving Africans. In that port, Black African Christians and Jesuits engaged in a similar project to position Black Africans as Christians (although for very different purposes), which differed drastically from Bartolomé de Las Casas's radical antislavery arguments of the mid-sixteenth century that positioned Africans as non-Christians. Representations of Africa as the site of ancient Christian Ethiopia allowed Jesuits in early seventeenthcentury Cartagena de Indias to argue for the just enslavement of all Africans, as they weaponized a history of a decayed ancient Christian Ethiopian church in order to posit that the mass enslavement of Africans, followed by forcible removals from Africa, would lead Black Africans back to the original Ethiopian church, which they positioned as an elected Black church in the New World. In other words, within such Jesuit discourses, the just enslavement of Africans emerged as a solution to the problem of conversion. On the other hand, enslaved Africans litigated for their freedom on the basis that their Christianity rendered their enslavement illegitimate, arguing that "there is no right [no hay derecho] to enslave between Christians." ${ }^{4}$

Interwoven throughout my analysis is a focus on how the Crown also shared some concerns about the potential unjust enslavement of Black African Christians, as it created juridical mechanisms for enslaved Africans to seek justice for their unjust enslavement. The establishment of legal avenues and procuradores (legal representatives) for such individuals to seek justice (even for those without any financial means) mirrors the Crown's provision of legal structures to protect enslaved Indigenous Americans against unjust war. ${ }^{5}$ In the case of Africans, however, the Crown recognized that the legal reasons for their unjust enslavement diverged significantly from those of unjustly enslaved Indigenous Americans. The Crown freed Indigenous Americans, not because they were Christians, but because they were not Christians when they had

${ }^{3}$ Archivo General de las Indias (hereafter AGI), Indiferente (hereafter Ind.), 1205, no. 21. I thank Nelson Fernando González Martínez for transcribing this source in Seville in 2017.

${ }^{4}$ Archivo General de la Nación de Colombia (hereafter AGN), Sección Colonia (hereafter SC), Negros y Esclavos (hereafter NE) 43, legajo 13, doc. 9, fol. $10^{\mathrm{r}}$.

${ }^{5}$ For the sixteenth century, see Van Deusen, 119. For discussions of just war between Crown, Jesuits, and Indigenous peoples in early seventeenth-century Chile, see Gaune Corradi; Valenzuela. 
been enslaved, while the Crown's reasoning with regard to Africans was precisely the opposite. The Crown liberated Africans on the basis that they were already Christians when they were enslaved in their respective places of origin in Upper Guinea and West-Central Africa. Enslaved Africans' intellectual histories of just enslavement thus had an impact on Iberian epistemologies and imperial rule, at least on a local level, as the Crown set free enslaved litigants on the basis that their captivity did not fall under the purview of just enslavement, and the Crown did so against the will of powerful merchant interests.

Enslaved Africans' freedom litigation suits illuminate the intimate entanglements of the lives, experiences, and ideas of individuals living in close urban quarters, who rarely receive scholarly attention under the same analytical gaze-namely, enslaved Africans, lettered theologians, and royal judges in local and metropolitan courts. Theological discourses propagated by theologians, for example, were connected to and shaped by the thoughts and practices of enslaved Black Africans who inhabited the same urban landscapes. Historians' calls to explore Atlantic history beyond the geographic boundaries of political entities by focusing on the entanglements of the early Atlantic world have inspired me to reimagine how to write an intellectual history that elucidates the connections between ideas that often appear to rest in separate intellectual spheres or registers within the same physical spaces-in this case, theological thought developed by missionaries and the legal strategies deployed by enslaved subjects in litigation suits. ${ }^{6}$ Plotting particular lives and lived experiences on an urban landscape makes visible the shared spaces where people from different backgrounds converged and shaped one another's ideas, be it in congregations, on slave ships, on street corners, or through word of mouth or hearsay in urban life. In this article, I trace the fragments, the webs, and the practices-sometimes written and sometimes in ephemeral conversations or through witness statements - to tell a story of how individuals from starkly different social worlds, who inhabited the same urban sites, affected and shaped one another's intellectual landscapes.

This exploration of enslaved Africans' impact on the discursive landscapes of the Iberian cities where they resided goes some way to position Black Africans as important actors in the intellectual history of the Atlantic world, in this particular case, within discourses of just and unjust slavery and the discursive landscapes of the various locales where they lived. The study contributes to a growing field of scholarship that seeks to redefine intellectual history by questioning the value placed on texts produced in Western European legislative, theological, or literary spheres, over the exchange of ideas in nonwritten contexts and among social strata that scholars often consider peripheral to an

${ }^{6}$ Cañizares-Esguerra, 2007 and 2018; Gould; Green, 2016. 
intellectual core. ${ }^{7}$ Focus in intellectual history on the ideas of lettered elites over other forms of intellectual exchanges historiographically marginalizes certain groups from participating in — and forging — intellectual traditions, thereby rendering them outside of history and devoid of ideas or an intellectual tradition. This analysis seeks to highlight the weakness of a scholarly tradition that constrains discourses of just war and just slavery to legislative or theological spheres in Western European thought, while disregarding how enslaved Africans may have engaged with, shaped, or redefined such discourses. ${ }^{8}$ In other words, the work addresses the epistemic erasure from intellectual histories of just war and just slavery of enslaved subjects' engagements with (or ideas about) the religious or legal discourses that structured the legality of their own enslavement in Iberian jurisdictions.

A thriving intellectual history existed across Upper Guinea and West-Central Africa regarding whether and how slavery was justified. These intellectual histories responded to local histories and shifting political environments and allegiances. John Thornton has highlighted a plural landscape of ideas about just slavery in Central Africa through an exploration of how three sixteenth- and early seventeenth-century leaders-King Afonso I (1509-42) of Kongo, Queen Njinga Mbande (1624-63) of Ndongo and Matamba, and King Garcia II (1641-61) of Kongo- each developed a series of ethical and legal considerations regarding just and unjust enslavement. ${ }^{9}$ Separately, with a focus on Upper Guinea and Senagambia, Toby Green, and Jennifer Lofkrantz and Andolatunji Ojo have explored stark variances in how polities across different regions in West Africa defined the conditions that legitimated enslavement. ${ }^{10}$ They have underscored complex negotiations between different polities about the legality of enslavement of vassals, and African communities' and polities' engagement in rescate and ransom negotiations to free unjustly or illegitimately enslaved subjects.

With a focus on the discursive landscape of a less powerful rung of African societies-namely, individuals who were themselves enslaved and forcibly displaced across the Atlantic Ocean-Mariana Armond Dias Paes, Mariana

${ }^{7}$ Al-Musawi, 1-20; Bennett, 2009, 1-22; Delmas; P. Gómez, 1-16; Jouve Martín, 1-205; Ramos and Yannikakis, 1-20; Rappaport and Cummins, 1-26; Rowe.

${ }^{8}$ Alencastro; Camplani; Cárdenas; Gaune Corradi, 1-486; Sánchez-Godoy, 2011 and 2016; Valenzuela; Vignaux, 33-83. One exception is Nancy Van Deusen's groundbreaking research into how enslaved Indigenous Americans in mid-sixteenth-century Seville developed (along with their lawyers) legal arguments for their freedom in response to the introduction of the New Laws in 1542 that prohibited the enslavement of Indigenous Americans: Van Deusen, $2-5$.

${ }^{9}$ Thornton, 2010.

${ }^{10}$ Green, 2012, 69-94; Lofkrantz and Ojo. 
Candido, Jose C. Curto, and Roquinaldo Ferreira have explored litigation-forfreedom suits in various courts in Angola in the age of the slave trade. They have explored the emergence in Angola of legal mechanisms to contest slavery that intermixed preexisting and new Indigenous legal structures and customs regarding just slavery, and the Portuguese Crown's development and provision of legal avenues for court cases regarding instances of unjust enslavement. For example, Ferreira explored the tribunal de mucanos, also known as tribunal da liberdade (tribunal of liberty), "an African institution incorporated into the Portuguese legal system by the middle of the seventeenth century that epitomized the interwoven nature of customs, power, and law in Portuguese Angola," and in which "so-called appeals for freedom were by far the most important matters judged," while Candido examined the establishment of an inquisidor das liberdades (inquisitor of freedom) in eighteenth-century Benguela. ${ }^{11}$ Curto and Candido have respectively also demonstrated that some enslaved litigants in the eighteenth and nineteenth centuries argued for the illegitimacy of their enslavement by deploying the concept of original freedom, which was "a right that had been granted to Africans by the Portuguese Crown almost from the beginning of the Angolan slave trade, that those 'unlawfully' enslaved would not be unjustly compelled to serve a life in bondage." 12 Collectively, their work highlights how Luanda and Benguela in Angola - two of the highest-volume slave-trading ports in eighteenth-and nineteenth-century Atlantic Africa-became epicenters of discourses on just and unjust slavery in the Atlantic world.

This study focuses on how enslaved Africans shaped legal discourses of just slavery in local and viceregal courts in the Spanish Empire that responded to various, and often plural, African and European legal cultures that defined the terms of just enslavement across different regions of West Africa and West-Central Africa. The discourses discussed in this article-just slavery and just war-were some of various legal strategies that enslaved Africans deployed in the courts in the Spanish Empire in an attempt to secure their freedom. For example, Herman L. Bennett, Adriana Chira, Alejandro de la Fuente, Karen Graubart, Michelle A. McKinley, and María Cristina Navarrete Peláez have explored how enslaved Africans litigated for their entire or partial freedom in royal, ecclesiastical, and inquisitorial courts in the Spanish Americas by employing diverse legal strategies that included seeking reprieve from undue physical violence from an owner; informing Inquisitors of an owner's heresy in order to later argue for freedom on the basis that heretics could not own slaves; arguing

${ }^{11}$ Candido, 2011; Candido, 2013, 191-236; Curto, 2003, 51-52; Curto, 2005 and 2008; Dias Paes; Ferreira, 88-125.

${ }^{12}$ Candido, 2011; Curto, 2003, 51-52. 
for a slave's right to cohabit with a spouse; seeking permission and a legal agreement to purchase one's own manumission at a future date or in installments (coartación); and positioning the importance of affective labor as a reason for manumission. ${ }^{13}$ This article contributes to this rich scholarship by highlighting how some enslaved Africans litigated for their liberty in royal courts on the basis that their Christianity rendered their enslavement illegitimate.

\section{JUST SLAVERY IN EARLY SIXTEENTH-CENTURY SEVILLE}

"Domingo, of black color, I say that I am free and natural [born in] of Gelofe": so commenced a 1536 petition that Domingo Gelofe submitted for his liberty to a fiscal (official) of the Council of the Indies who was stationed in Seville. ${ }^{14}$ Domingo described himself as a free Black man from the land of Gelofe, son of a hombre principal (honorable man), and a Christian who had willingly left his land of naturaleza (the term refers to someone's place of birth, as well as being part of a "community of belonging" as a result of the place of birth) in order to become better indoctrinated in Christianity. ${ }^{15}$ Domingo engaged in a conversation through his 1536 petition with Castilian rulers who possessed a deep awareness of his place of origin, the land of Gelofe (most likely, the Jolof Empire in the Senegambia valley). Since at least the early fifteenth century, Portuguese and Castilian monarchs were aware of the kingdoms and polities that constituted Western Africa, and particularly of the Jolof "expansionist kingdoms" and the subsequent political fragmentation of the Jolof Empire in the fifteenth century. ${ }^{16}$ These political pressures had led to Jolofs figuring among the majority of Africans who were enslaved and exported to the Atlantic world in the early sixteenth century. ${ }^{17}$ An uprising led by Jolof slaves in 1522 in Isla Hispaniola (present-day Haiti and the Dominican Republic) led to a decade-long attempt by the Spanish Crown to prohibit slave traders from exporting enslaved Gelofes to the Spanish Indies. ${ }^{18}$

In his 1536 petition to the Council of the Indies, Domingo relayed that he had developed relationships through trade and friendship with Portuguese traders in Gelofe. He described how he voluntarily decided to leave Gelofe with a

${ }^{13}$ Chira; Bennett, 2009, 1-22; Fuente, 2011, 147-222; Fuente, 2004; Fuente and Gross, 13-78; McKinley, 1-73; Navarrete Peláez, 2017.

${ }^{14}$ AGI, Ind., 1205 , no. 21 , fol. $1^{\mathrm{r}-\mathrm{v}}$.

${ }^{15}$ For discussion of naturaleza, see Herzog; Ireton.

${ }^{16}$ Green, 2012, 69-94; Bennett, 2018, 1-15.

${ }^{17}$ Green, 2012, 69-94; M. Gómez, 3-46; Wheat, 2011.

${ }^{18}$ See, for example, "General R.C. Confirmando la Prohibición de que los esclavos Gelofes pasen a Indias, Segovia, 28 de Septiembre de 1532" (Royal decree prohibiting that slave traders take enslaved Gelofes to the Indies, 28 September 1532), transcribed in Lucena Salmoral, 45. 
Portuguese trader in order to learn more about Christianity and to become fluent in the language of the Christians. Domingo and his Portuguese party reportedly departed Gelofe and arrived at the island of Tenerife in approximately 1529/30. In Tenerife, Domingo explained how a captain in a Spanish armada had illegitimately captured him. Domingo soon found himself aboard the fleets of an early sixteenth-century conquistador named Diego de Ordás, crossing the Atlantic Ocean in search of El Dorado. ${ }^{19}$ Ordás had left the town of San Lucar de Barrameda, located on the mouth of the Guadalquivir River in southern Castile, on 20 October 1530 with five hundred men and thirty horses, and at least one Indigenous American interpreter. ${ }^{20}$ The fleets docked in Tenerife, where Ordás possessed a royal license to source an extra one hundred men and horses for his armada, and where the fleet would also collect provisions for the journey. ${ }^{21}$ Domingo's forced Atlantic journey in 1530 from Tenerife to the Indies lasted two years as the armada reached the Gulf of Paría (present-day coastal Venezuela) and returned to Castile in 1532, while Ordás perished at sea. ${ }^{22}$ During the two-year Atlantic odyssey, ownership of Domingo transferred from the captain who had reportedly snatched him in Tenerife to Diego de Ordás, suggesting that perhaps Domingo became the personal slave to the conquistador at the helm of the armada. ${ }^{23}$ After the surviving members of the armada returned to Castile in 1532, House of Trade officials in Seville ordered that Domingo be distributed, along with Ordás's other property, among the heirs of the deceased conquistador. ${ }^{24}$

Domingo's knowledge of Iberian ideas of just war and the illegitimacy of Christians enslaving other Christians may have stemmed from his conversations and relations during the two years that he spent on the fleets of Ordás's armada, or during the four years that he subsequently spent living enslaved in Seville. But Domingo's petition to the Castilian monarch for his liberty should also be read as an intellectual history of slavery from his native Tierra Gelofe. First, Domingo's explanation that the illegitimacy of his enslavement rested on his voluntary departure from Tierra Gelofe may correlate to ideas about just war in the Jolof Empire. Custom in Jolof kingdoms (and Senegambia more broadly) specified that wars between major political foes justified slavery,

${ }^{19}$ AGI, Ind., 1205, no. 21, fol. $1^{\mathrm{r}-\mathrm{v}}$.

${ }^{20}$ AGI, Ind., 416, 1. 3, fol. $19^{\mathrm{v}}$; AGI, Ind., 416, 1. 3, fol. $19^{\mathrm{r}-\mathrm{v}}$.

${ }^{21}$ AGI, Ind., 416, 1. 3, fol. $23^{\mathrm{v}}$; AGI, Ind., 416, 1. 3, fols. $34^{\mathrm{v}}-35^{\mathrm{r}}$.

${ }^{22}$ AGI, Justicia, 712, no. 1.

${ }^{23}$ AGI, Ind., 1205, no. 21.

${ }^{24}$ For studies on the House of Trade and bienes de difuntos (assets of the deceased), see Almorza Hidalgo; Gónzalez Sánchez; Ireton, 591-92; Mangan, 145-71; Tempère, 19-56. 
and not intra-lineage and village raids, as was common in Upper Guinea, for example. ${ }^{25}$ Consequently, as Toby Green has argued, most captives from Jolof were "war captives procured through attacks from Cajor and the Sereer." 26 Second, Domingo's legal strategy to identify as a Christian in order to argue for the illegitimacy of his enslavement may be the result of his exposure to ongoing inter-African creolization processes in the Jolof kingdoms or syncretic New Christian-Sephardic-Senegambian communities that emerged in the late fifteenth and early sixteenth centuries on the Petite Côte in Senegambia, following the settlement of exiled New Christian communities from Iberia and Amsterdam. ${ }^{27}$ Descendants of New Christian-SephardicSenegambian communities formed part of extensive trading networks and possessed a deep knowledge of Iberian laws and Catholicism.

Domingo's appeal to the Crown in 1536 also suggests an engagement with broader discussions about just war that were ongoing in Seville, the city where he languished for four years as a domestic slave prior to submitting his petition for freedom in 1536. Domingo's petition suggests that he was deeply embedded in contemporaneous discourses of empire, just war, Catholicism, and royal vassalage in Seville, particularly with debates concerning the just enslavement of Indigenous Americans. As Nancy Van Deusen has cataloged, early sixteenthcentury Seville became a site of ferocious debates about the legitimacy of the enslavement of Indigenous Americans, following the forcible displacement of more than 650,000 Indigenous Americans through slavery within the Indies. Over two thousand Indigenous Americans had been brought to Castile, mostly to Seville, as slaves. ${ }^{28}$ Dominican friar Bartolomé de Las Casas was involved in a protracted effort to outlaw the enslavement of Indigenous Americans in the New World on the basis that such enslavements did not result from just wars. ${ }^{29}$ Such debates resulted in what Van Deusen described as the passing and rescinding of "contradictory and piecemeal" Crown legislation in Castile that "excluded slavery only in some areas, temporarily prohibited slavery (1530), and later reestablished slavery under conditions of just war and ransom $(1534,1550)$, and granted exceptions to individual merchants and families making transatlantic journeys to Castile by ignoring laws that prohibited the transportation of slaves away from their places of origin." 30

${ }^{25}$ Green, 2012, 91.

${ }^{26}$ Green, 2012, 69-94.

${ }^{27}$ Green, 2012, 69-148; Mark and Horta, 1-102.

${ }^{28}$ Van Deusen, 2.

${ }^{29}$ Brunstetter; Castro; Clayton, 82-120; Hanke; Orique; Orique and Roldán-Figueroa, $195-436$.

${ }^{30}$ Van Deusen, 5. 
Finally, the Crown introduced the New Laws in 1542, which prohibited Indigenous slavery. As Van Deusen has explored, the New Laws were followed by two royal inspections in the city of Seville in 1543 and 1549, which sought to investigate whether any Indigenous Americans continued to be illegitimately enslaved in that city and its environs, and resulted in the manumission of one hundred Indigenous individuals.

A thriving discourse therefore existed in Castile, and particularly in Seville, in the 1530s regarding the just enslavement of Native Americans. The discourse was not limited to theological and royal spheres, as neighbors and friends on street corners in Seville and neighboring towns also discussed and debated the law with regard to just war and Indigenous slavery. As Van Deusen has illuminated, hundreds of enslaved Indigenous Americans in Castile who brought cases to the Spanish courts to secure their freedom between 1530 and 1585 shaped discourses of just slavery through their litigation and the act of seeking witness testimonies from their friends and neighbors. Van Deusen suggested that the New Laws in 1542 led to "word spread[ing] quickly among Indios [Indigenous Americans] in Castile that they could litigate for their freedom and that they were exempt from court costs." 31 City dwellers also heard about broader discussions concerning the unjust enslavement of Indigenous Americans through town criers who would sing royal decrees announcing the prohibition of Indigenous slavery on the steps of Seville's cathedral. Further, the two royal inspections in Seville, in 1543 and 1549, both of which sought to investigate whether any Indigenous Americans remained enslaved after the royal prohibitions, had a pronounced effect on masters and enslaved Indigenous people in the city: the "1543 inspection caused a major stir in Seville. It struck deep, raw nerves, triggering panic among slave owners and causing desperation and profound anxiety among freedpersons. The charged atmosphere was still palpable when Las Casas reached his home base of Seville in 1544 to prepare for his last voyage to America."32

Significantly, Van Deusen analyzed how Indigenous petitioners' argumentsthrough the guidance of legal defenders, but also through word of mouth between petitioners and witnesses- had begun between 1543 and 1549 "to echo the theological debates taking place among several Dominican and Jesuit theologians who had been influenced by Francisco de Victoria." ${ }^{3}$ The royally appointed procurador for Indigenous captives, Diego de Pantoja, "advised indigenous litigants to make three separate but interrelated claimsthat they were free by birth [de su Nacimiento]; that they were free by their

\footnotetext{
${ }^{31}$ Van Deusen, 19.

${ }^{32}$ Van Deusen, 111.

${ }^{33}$ Van Deusen, 119.
} 
nativeness [naturaleza] based on their place of origin; and that they were free by their ingenio, or capacity as rational beings." 34 The high success rate- 95 percent of the petitions resulted in Indigenous litigants obtaining their freedomalso contributed to the circulation of know-how about royal petitioning and debates regarding the illegitimate slavery in Seville and its environs. In particular, Van Deusen found that former Indigenous petitioners tended to remain in Castile upon obtaining their freedom and would later serve as witnesses in their neighbors' and friends' petitions for liberty.

Domingo's petition illustrates that debates about just slavery in Seville also extended to the enslavement of Black Africans. Such a development is not surprising given that free Black individuals from Seville and the nearby town of Carmona often attested to Indigenous litigators' American naturaleza in their trials for unjust enslavement. ${ }^{35}$ In so doing, these Black witnesses played a role in shaping discourses of just war and Indigenous Americans' unjust enslavement in Seville's courts. One might surmise that that Black dwellers of Seville who provided witness testimonies in Indigenous cases for unjust enslavement might have also begun to question the legitimacy of the enslavement of Black Africans. Familial and commercial ties between Black witnesses living in Carmona and Seville, as documented by Van Deusen, also highlight how ideas and knowledge about Indigenous trials circulated between Black residents in neighboring towns in southern Castile.

Ties between free and enslaved Black Africans living between Seville and Carmona were the tip of an iceberg. Seville's Black population in the early decades of the sixteenth century was geographically heterogeneous and connected to broader sites in Castile and the Spanish Empire. ${ }^{36}$ For example, House of Trade passenger seat records from the first half of the sixteenth century for formerly enslaved free Black individuals who embarked from Seville to the Indies show the locations where notaries had formalized Black passengers freedom certificates and offer a snapshot of free Black individuals' varied sites of naturaleza within Castile and beyond Seville, including the towns of Alcalá de Guadaira, Jerez de la Frontera, Morilla de la Sierra, Pontevedra, Ronda, Sanlúcar la Mayor, Seville, Valencia (de Alcántara), Valladolid, and Zafra. ${ }^{37}$

${ }^{34}$ Van Deusen, 119.

${ }^{35}$ Van Deusen, 46, 55.

${ }^{36}$ Pérez García and Fernández Chaves; Ireton; Pike.

${ }^{37}$ From 1509 to 1549, I have located fifty-six records of free Black men and women obtaining permission to travel to the Indies. For example: AGI, Cont., 5536, 1. 1, fols. $6^{\mathrm{r}-\mathrm{v}(1)}, 153^{\mathrm{r}-\mathrm{v}(4)}$, $417^{\mathrm{r}-\mathrm{v}(4)}, 507^{\mathrm{r}-\mathrm{v}(8)}, 469^{\mathrm{r}-\mathrm{v}(12)}$; AGI, Cont., 5536, 1. 2, fols. $32^{\mathrm{r}-\mathrm{v}(2)}, 63^{\mathrm{r}-\mathrm{v}(5)}, 91^{\mathrm{r}-\mathrm{v}(2)}, 112^{\mathrm{r}-\mathrm{v}(1)}$; AGI, Cont., 5536, 1. 3, fols. $215^{\mathrm{r}-\mathrm{v}(6)}, 257^{\mathrm{r}-\mathrm{v}(4)}, 358^{\mathrm{r}-\mathrm{v}(6)}$; AGI, Cont., 5536, 1. 5, fols. $78^{\mathrm{v}(4)}$, $84^{\mathrm{r}(3)}, 156^{\mathrm{r}(1)}, 202^{\mathrm{r}(3)}$. 
The geographic itinerancy of free and formerly enslaved Black individuals between Seville and other locales in Castile and the Indies raises important questions about the movement of ideas and discourses across and between Black populations in Castile and beyond, and especially with regard to ongoing debates about just slavery in Seville. Individuals who moved between sites took a world of experiences, memories, and ideas from the various places where they had resided.

A discourse about the unjust enslavement of Africans also developed in Seville in this period because Bartolomé de Las Casas-whose fame in Seville for his role in the prohibition of Indigenous American slavery was significantalso came to view African slavery in similarly unjust terms. In 1552, Las Casas wrote a scathing attack of the enslavement of Africans in Brevisima relación de la destrucción de Africa. ${ }^{38}$ Las Casas argued that only three acceptable causes existed for a just war against infidels and their enslavement, and that no such conditions existed for just enslavement anywhere in Atlantic Africa between the Canary Islands and the Cape of Good Hope. ${ }^{39}$ The first cause related to contexts where infidels waged war against Christians and attempted to destroy Christianity. Only the Turks of Berbery and the Orient counted in this claim, argued Las Casas, because they waged war against Christians every day and had a long history of showing intent to harm Christians. There was thus no doubt that the Turks were engaged in a just war against Christians. In fact, to Las Casas, Christians should not even coin such a situation as a just war, but instead as a legitimate and natural defense. The second cause related to when infidels persecuted and disturbed or maliciously impeded the Christian faith and religion-for example, by killing its devotees and preachers without any legitimate cause, or by forcing Christians to renege on their faith. Such acts hindered and persecuted the Christian faith and were grounds for just war and enslavement. The third and final reason that would allow for a just war in Africa applied when infidels attempted to prevent or conquer Christian kingdoms. Las Casas added that under no circumstances could an individual's infidel status alone serve as a just cause for his or her enslavement. According to Las Casas, none of the three just causes existed in Atlantic Africa between the Canary Islands and the Cape of Good Hope in the fifteenth century, nor subsequently. Las Casas's radical argument essentially proposed that there was no legal or theological basis to justify Portuguese traders' enslavements of "blacks and moors" in Upper Guinea and West-Central Africa.

In short, by the mid-sixteenth century, Las Casas rejected the enslavement of Africans as illegitimate; the practice was as abhorrent and illegal as the

\footnotetext{
${ }^{38}$ Camplani; Las Casas, 253-56; Sánchez-Godoy, 2011 and 2016.

${ }^{39}$ Las Casas, 253-56.
} 
enslavement of Indigenous people in the Americas. And to Las Casas, the representation of Africa as a pagan land with no previous contact with Christianity rendered the enslavement of Black Africans as unjust-parallel to his view of Indigenous Americans. Las Casas posited that King D. Juan III of Portugal had realized the legal error of trading slaves with Muslims and had prohibited the practice, but that the monarch had failed to realize the widespread sin of stealing Black individuals from their lands. Las Casas wrote, "but he [D. Juan III] did not prevent the rescate and the one thousand mortal sins that are committed in it, swelling the world of Black slaves, at least in Spain, and even making our Indies overflow with them." ${ }^{40}$ Las Casas noted, "of more than 100,000 [Black slaves], it is not believed that more than 10 had legitimately been enslaved." ${ }^{\prime 1}$ Such refutations of the practice of enslavement of Black Africans did not result in broader antislavery discourses regarding African slavery that would parallel the ferocious debates pertaining to the enslavement of Indigenous Americans that took place mere decades earlier in Castile and the subsequent legislation outlawing their enslavement. ${ }^{42}$ But Las Casas's refutation of the legality of the enslavement of Black Africans demonstrates the existence of debates in the sixteenth century, especially in Seville, about the legitimacy of the enslavement of Black Africans through a reductive representation of Africa as a pagan land.

Black Africans' legal arguments regarding the unjust enslavement of Africans engaged with these broader contemporaneous discourses of just slavery in Seville, while developing distinct legal arguments specific to a notion of Black Christianity and just war. Enslaved African litigants represented Africa as a Christian region that predated contact with the Portuguese. For example, Domingo Gelofe's litigation highlights a radically different conception of the unjust enslavement of Africans to the arguments proposed by Las Casas. ${ }^{43}$ Domingo did not propose that a lack of a legitimate just war in Africa meant that the enslavement of Black Africans per se was unjust, as Las Casas proposed. Instead, Domingo argued that it was the enslavement of Black African Christians that was unjust. Domingo played on four issues in his petition: (1) his father being a Black African with honor; (2) Domingo being a Christian prior to meeting the Portuguese; (3) his curiosity to voluntarily travel with the Portuguese traders to the Iberian world in order to learn more about

\footnotetext{
${ }^{40}$ Las Casas, 267.

${ }^{41}$ Las Casas, 267.

${ }^{42}$ For another sixteenth-century theologian who posited the illegitimacy of the enslavement of Africans, see Fray Alonso de Montúfar's (1489-1572) letter to the king, in Lucena Salmoral, 88-89; Sierra Silva, 40-42. See also Alencastro.
}

${ }^{43}$ AGI, Ind., 1205 , no. 21 , fol. $1^{\mathrm{r}-\mathrm{v}}$. 
the Christian faith and the Christian languages; (4) the conquistador, Diego Ordás, recognizing that Domingo was a free man who had been illegitimately enslaved, and subsequently freeing Domingo. Domingo's legal argument of unjust slavery thus relied on the notion that he was already a Christian in Gelofe, which therefore rendered any enslavement illegitimate. This was opposite to the arguments put forward by Indigenous Americans seeking their freedom on the basis of unjust slavery in Seville courts. Their legal petitions centered on their illegitimate enslavement stemming precisely from the fact that they were not Christians at the time of their capture. ${ }^{44}$ Domingo's arguments about unjust slavery were far closer to the Black literatus Juan Latino's discourse of an Ethiopian Christianity in sixteenth-century Granada-an African Christianity in an alliance with Hispanic Catholics, and whose flock could not be legitimately enslaved-than to Bartolomé de Las Casas, whose proposal for Africans relied on the logic that while their enslavement was wholly unjust, Africans were nonetheless not Christians. ${ }^{45}$

Strikingly, the monarch's response to Domingo's petition highlights an element of doubt in the official mind of the Spanish Empire (in this case, the Council of the Indies) with regard to the just enslavement of African Christians. In 1537, a year after launching his petition with the Seville-based representative of the Council of the Indies, Domingo obtained a royal decree issued by the Consejo de Indias that guaranteed his status as a free man. ${ }^{46}$ The royal decree stated unequivocally that Domingo "of black color" was-and always had been-free, and should be treated as a free man in all of the kingdoms of Castile, the Indies, and Tierra Firme. The decree reasoned that not only had Diego de Ordás freed Domingo in his testament, but that Domingo's freedom was guaranteed because he "came with them [the Portuguese] to be a Christian, as he is," suggesting that the Crown agreed with Domingo as to the illegitimacy of his entire ordeal in captivity because of his status as a free Christian in Tierra Gelofe. The existence of the royal decree suggests that the Crown's view on the legitimacy of African slaveryespecially with regard to Christians-was also piecemeal and reactionary to individual petitions. ${ }^{47}$ Domingo's petition of 1536 and the royal response in 1537 demonstrate the existence of a discussion between rulers and ruled about the legitimacy of African slavery in the early decades of the sixteenth century, especially in relation to Black African Christians. As I explore below, such

\footnotetext{
${ }^{44}$ Van Deusen, $150-59$.

${ }^{45}$ Martín Casares; Latino; Wright, 87-181.

${ }^{46}$ AGI, Ind., 422, 1. 17, fols. $114^{\mathrm{r}}-115^{\mathrm{r}}$, and all further quotations in this paragraph.

${ }^{47}$ Masters.
} 
discourses continued and transformed in royal courts in later decades across other sites of the Spanish Empire.

I have located four historical records pointing to Domingo's life in Seville between 1532 and 1538: the 1532 assets of the deceased case for Ordás, in which House of Trade officials judged that Domingo was a slave of the deceased and would be inherited by one of Ordás's heirs; Domingo's 1536 petition for his freedom to the Council of the Indies; the 1537 royal decree establishing Domingo's freedom; and a 1538 record of a travel license application at Seville's House of Trade for Domingo to travel as a free man to Peru. ${ }^{48}$ The available evidence thus suggests that the royal decree that stipulated Domingo's freedom in 1537 resulted in Domingo obtaining a status as a free man, as he applied the following year for a royal license to travel to Peru. House of Trade officials recorded Domingo as a free Black man in his travel record in 1538, and noted the existence of the 1537 royal decree that established Domingo's freedom. ${ }^{49}$ Domingo's travel record also specified that he left Seville to Peru employed as a criado (servant); Domingo may well have contracted his labor as a servant for a specified time period in order to pay for his Atlantic crossing, as did other free Black individuals who crossed the Atlantic in the time period under study, or he may have found himself in a state of forced servitude even though he was legally free. ${ }^{50}$ Although I have not located any further archival evidence to trace Domingo's life after his departure from Seville to Peru as a free man, it might not be too far-fetched to suggest that in the process of traversing the Atlantic Ocean and his probable sojourns in various ports and regions until reaching Peru, that Domingo might have established ties along the route and discussed his litigation for freedom with those he encountered during his journey and in Peru.

\section{EARLY SEVENTEENTH-CENTURY CARTAGENA DE INDIAS}

Representations of a Christian Africa became central to discourses concerning just slavery in early seventeenth-century Cartagena de Indias, the highestvolume slave-trading port of the Spanish Atlantic. In that port, groups with vastly different interests, who inhabited-sometimes in close quarters-the same urban space became invested in arguing for the existence of Christianity in Africa. Exploring theological discourses about African Catholicism and just slavery among Jesuits based in early seventeenth-century

\footnotetext{
${ }^{48}$ AGI, Justicia, 712, no. 1; AGI, Ind., 1205, no. 21; AGI Ind., 422, 1. 17, fols. $114^{\mathrm{r}}-115^{\mathrm{r}}$; AGI, Cont., 5536, 1. 5, fol. $156^{\mathrm{r}(1)}$.

${ }^{49}$ AGI, Cont., 5536, 1. 5, fol. $156^{\mathrm{r}(1)}$.

${ }^{50}$ Ireton; Garofalo.
} 
Cartagena and a litigation suit in Cartagena courts for freedom on the basis of unjust enslavement elucidates how a flourishing discursive landscape about African Christianity emerged in that port.

On 5 June 1614, a Portuguese converso (descendant of Jewish converts to Christianity) captain named Antonio Rodriguez steered his ship loaded with a cargo of enslaved Africans into the port of Cartagena de Indias. Another Portuguese converso and former Seville vecino (loosely, resident), Manuel Bautista Pérez, was also aboard the vessel, probably keeping a watchful eye on his first large-scale purchase of enslaved Africans, whom he had just acquired during a slave-trading enterprise to the port town of Cacheu in Upper Guinea (in present-day Guinea-Bissau) between 1613 and $1614 . .^{51}$ A novice to the transatlantic slave trade and lacking in personal capital, Bautista Pérez had purchased most of the African captives as an agent for wealthier merchantsnamely, his Lisbon-based uncle, who formed part of a broad Portuguese converso family network of slave traders operating between Lisbon, Seville, Guinea, and the Spanish Indies. ${ }^{52}$ Bautista Pérez had spent ten months in Cacheu, where he benefited from the local know-how of his brother who resided on the Guinean coasts, in addition to a network of Portuguese converso residents in the African port. ${ }^{53}$ Also onboard the ship that arrived in Cartagena, among the enslaved cargo, was a young Black African captive named Francisco Martín, who hailed from the port of Cacheu. ${ }^{54}$ This coterie of characters who crossedor were forcibly displaced across - the Atlantic became embroiled in a legal case in Cartagena that centered on questions of just slavery, which lasted from July 1614 to May $1616 .{ }^{55}$ Upon arriving in Cartagena in June 1614, Francisco Martín litigated for his freedom on the basis that his enslavement in Africa had been unjust. ${ }^{56}$

Francisco Martín's first encounter in Cartagena de Indias-or more likely, in a bay where the ship would have docked prior to arriving at the port-may have been with Jesuit priest Alonso de Sandoval (1576-1652) and his coterie of free and enslaved African interpreters. This is because Martín arrived into a spiritual world in Cartagena de Indias that was concerned with null baptisms and just slavery. ${ }^{57}$ Cartagena-based Jesuit Alonso de Sandoval, and later his disciple

${ }^{51}$ AGN, SC, NE 43, legajo 13, doc. 9. This journey is listed on the Trans-Atlantic Slave Trade Database as voyage n.28143.

${ }^{52}$ Newson and Minchin, 1-17.

${ }^{53}$ Green, 2019, 136-38; Newson and Minchin, 22; Newson.

${ }^{54}$ AGN, SC, NE 43, legajo 13, doc. 9.

${ }^{55}$ AGN, SC, NE 43, legajo 13, doc. 9.

${ }^{56}$ AGN, SC, NE 43, legajo 13, doc. 9.

${ }^{57}$ Brewer-García; Cárdenas; Queija; Vignaux, 33-83. 
Pedro de Claver (1580-1654), who joined the Cartagena Jesuits in 1615, dedicated their missionary energies to tending to enslaved Africans' souls. Sandoval, in particular, became concerned, through his contact with enslaved Africans in Cartagena, that many baptisms that took place in "those lands [Africa], and ships" were "commonly null and at least doubtful." 58 That concern strengthened Sandoval's sense of the importance that priests in the principal ports of disembarkation of African slaves- "Lisbon, Seville, the Baya, Pernambuco, Rio Geneyro, Buenosayres, San Iuan de Lua, Puertorico, Cartagena, Panama, and Lima, and wherever else boats arrived to sell captives" - had the obligation to examine whether null baptisms had taken place, and to "examine, catechize, and baptize those blacks that bring Christian names, and ordinarily are not Christians." Sandoval urged priests to meet ships as they arrived, before "[slave traders] commence to sell and distribute them [enslaved Africans] to different places." This was necessary, he argued, because slave owners and priests in other regions of the Indies tended not to doubt the baptism of enslaved black Africans as they were persuaded that "having passed through the port that they [enslaved people] will already have been baptized." Sandoval outlined that priests in ports should determine, as soon as ships arrived, whether enslaved Black Africans were "of Jesus Christ, and his church, and upon discovery that they are not, to ensure that they become so." For such purposes, the Cartagena Jesuits trained a cadre of skilled African interpreters who aided in communicating with enslaved individuals of varied African linguistic backgrounds, noting that "if speaking to them through their languages and interpreters, we will judge by the responses that they give to the questions that we ask them." 59

When enslaved individuals who had survived brutally violent displacements from Africa arrived as cargo on slave ships in Cartagena de Indias, such vessels tended to spend some days anchored in bays prior to docking at the port. That is when Sandoval and Claver or their African interpreters would row from Cartagena to the anchored ships in order to meet the captives and conduct extensive investigations into the Africans' religious knowledge and determine their spiritual needs, principally whether or not they had been correctly baptized in ports in African coasts. ${ }^{60}$ Upon reaching land, Claver would reportedly perform elaborate baptisms in which he became assured, through interpreters, that

\footnotetext{
${ }^{58}$ Sandoval, 1627, Bibliothèque nationale de France (hereafter BnF), département réserve des livres rares (hereafter LR), 4-O3C-6, book 3, chapter 1, fols. $286^{\mathrm{v}}-287^{\mathrm{r}}$, and for all further quotations in this paragraph. All translations of Sandoval are my own, except fols. $65^{\mathrm{r}}-70^{\mathrm{v}}$, which are translations by Nicole von Germeten, in Sandoval, 2008, 50-55.

${ }^{59}$ On Black interpreters in Cartagena, see Brewer-García; Vignaux, 327-504.

${ }^{60}$ Splendiani and Aristizábal Giraldo, 84-124.
} 
his enslaved flock understood the meaning of the baptism and wished to become Christians. ${ }^{61}$ Had Francisco Martín encountered Alonso de Sandoval and his African interpreters upon arriving in Cartagena-either while still on the ship or upon disembarking-Sandoval would have soon discovered that there was no need for an interpreter, for Martín spoke Spanish (and perhaps Portuguese too), and nor was there need for a baptism as Martín was well versed in his Christian faith. Martín may also have informed his Jesuit interlocutors that he was free and that his enslavement was unjust, because three months earlier, the slave trader aboard the same ship, a Portuguese converso merchant named Manuel Bautista Pérez, had illegitimately purchased him from another Portuguese trader in the port of Cacheu. ${ }^{62}$ On the other hand, Martín may well have been justifiably suspicious of priests in and around slave-trading ports, as he later recounted that his illegitimate enslavement had taken place at the hands of a priest named Manuel de Sossa on a beach in Sierra Leone. ${ }^{63}$

Martín disembarked from Antonio Rodrigues's ship in June 1614 into what ostensibly might be regarded as an African city. Early seventeenth-century Cartagena de Indias served as the epicenter of the Atlantic trade in enslaved Black Africans who hailed from various regions of Upper Guinea and WestCentral Africa. From Cartagena, merchants sold slaves for onward journeys to Lima, Panama, and New Spain, while other enslaved Africans remained in Cartagena or were displaced inland to New Granada. ${ }^{64}$ The port city thus comprised a large, transient population of African captives. In addition, the demography of Cartagena's urban landscape was composed of Black domestic slaves, free Black vecinos, and increasingly large communities of runaway former slaves in the hinterlands who established palenques (Maroon communities) and maintained ties with captive and free Black populations in urban centers. ${ }^{65}$ The large Black population of the port—especially the free Black individuals—also caused concern among royal officials and Spanish vecinos. A Tribunal of the Holy Office of the Inquisition was established in Cartagena in 1610, mainly to police Black ritual healing practitioners, especially among African women. ${ }^{66}$ The port also served as a major crossroads for travelers traversing between Castile and the Spanish Americas, and thus comprised an almost permanent population of

${ }^{61}$ Brewer-García; Splendiani and Aristizábal Giraldo, 84-124.

${ }^{62}$ AGN, SC, NE 43, legajo 13, doc. 9, fols. $3^{\mathrm{r}}-4^{\mathrm{r}}$.

${ }^{63}$ AGN, SC, NE 43, legajo 13, doc. 9, fols. $3^{\mathrm{r}}-4^{\mathrm{r}}$.

${ }^{64}$ O'Toole, 1-16, 35-63.

${ }^{65}$ On free Black vecinos, see Germeten; P. Gómez; Vidal Ortega; Wheat, 2016. On Black palenques in Nueva Granada, see Brewer-García, 116-63; Landers; McKnight; Navarrete Peláez, 2003, 2011, and 2015.

${ }^{66}$ Splendiani, Sánchez Bohórquez, and Luque de Salazar, 2:35-459; P. Gómez, 1-16. 
transient passersby, including free Black individuals, who sojourned in Cartagena while organizing logistics for their onward journeys. ${ }^{67}$

The world of commerce, slave trading, and policing of Catholic religiosity in Cartagena de Indias was not unfamiliar to Francisco Martín. Cartagena's role as a key port city in the transatlantic slave trade occupied a similar position to his native Cacheu in the Atlantic world during the previous half century. As Alonso de Sandoval described in 1627, following extensive interviews with enslaved Africans, slave traders, and priests, "[Cacheu] is the most important port of all of Guinea. Ships from Seville, Portugal, the island of Santiago and many other places come here to trade in Black slaves and many other things," while noting that Cacheu also had "a trading port, market, and church, which has a priest appointed by the king." 68 Martín had been born in the household of a Portuguese captain in Cacheu to free Black parents who hailed from the Capi nation and Cabo Verde, and would later testify to knowing most of the Portuguese converso merchants who resided in that port and those who passed through on slave-trading ventures. ${ }^{69}$ It is possible that Martín formed part of the Kriston community in the port of Cacheu-otherwise known by the Portuguese as Christianized Africans-who came to play a prominent role in facilitating trade and commerce between European traders and different African rulers; Martín and his African witnesses argued that his parents were well known as free Black Christians in Cacheu. ${ }^{70}$

Martín also testified that he labored as a wage-earning grumete on Portuguese ships along the coasts of Guinea, Sierra Leone, and Gambia. ${ }^{71}$ Historian Philip Havik defined grumetes of Cacheu as "Kristo rowers, pilots, interpreters, and petty traders, who acted simultaneously as traders and brokers, negotiating with African and Atlantic actors, whose existence therefore depended and thrived on making themselves indispensable." ${ }^{\prime 2}$ Havik pointed out that Kriston actors such as grumetes and tungumás (free Christian women from coastal ethnic groups) "formed an internal African trading diaspora that scouted the coast for commodities, while building and mediating extensive patron-client relations with local African elders and chiefs along its shores." ${ }^{\prime 3}$ Indeed, as a

${ }^{67}$ Ireton.

${ }^{68}$ Sandoval, 1627, BnF, LR, 4-O3C-6, book 1, chapter 12 , fols. $38^{\mathrm{r}}-41^{\mathrm{r}}$.

${ }^{69}$ AGN, SC, NE 43, legajo 13, doc. 9, fols. $3^{\mathrm{r}}-4^{\mathrm{r}}$.

${ }^{70}$ Havik, 2009 and 2012.

${ }^{71}$ AGN, SC, NE 43, legajo 13, doc. 9. For discussion of Africans employed on trading expeditions from Guinea to Sierra Leone, see Newson, 13-14.

${ }^{72}$ Havik, 2012.

${ }^{73}$ Havik, 2012. For further definitions of Kriston and tungumás, see Green, 2012, 260-77; Green, 2017; Havik, 2012, 321-22. 
wage-earning grumete on Portuguese slave-trading fleets around Cacheu in Guinea and in Sierra Leone, Martín came into contact with a wide array of Europeans and Africans who traveled and traded in Castile, Portugal, the Indies, and Africa, in addition to enslaved Africans who were forcibly removed from African shores as slaves. ${ }^{74}$ Exemplary of such relationships, Martín testified that Antonio Rodrigues, the captain of the ship in which Martín had been forcibly displaced from Cacheu to Cartagena, had known Martín for many years as a free man in Cacheu, while Martín claimed to know three other Spanish merchants or captains who arrived in Cartagena between June 1614 and March 1615 from his time in Cacheu and Sierra Leone. ${ }^{75}$

Finally, Martín would not have been surprised by the presence of priests in Cartagena de Indias, nor by the reach of the Holy Office of the Inquisition that had recently been established in the port in 1610. Martín was intimately acquainted with Iberian Catholicism. In Cacheu and surrounding locales, inquisitorial investigations into residents-both Black Christians and Portuguese conversos- had been active since 1540 (just four years after the establishment of the Holy Office of the Inquisition in Lisbon). ${ }^{76}$ In Cacheu, inquisitorial authorities persecuted Black Christian women for ritual healing practices, much like Inquisitors would do in Cartagena after $1610 .{ }^{77}$

Martín thus arrived in Cartagena in 1614 with significant know-how of the Atlantic world, Iberian laws, and Atlantic commercial systems, and well versed in the meaning and significance of a Christian profession of faith in the early Iberian Atlantic. But he also arrived in a port city where residents possessed intimate knowledge and awareness of well-established Christian pockets in Africa, and, as I analyze below, where reductive representations of an ancient Christian Africa carried particular currency among theologians. Sandoval, the Cartagenabased Jesuit who had spent his career investigating enslaved Africans' places of origin, recognized that some Black Christians lived in Cacheu, as he noted "many people have been successfully baptized here," but offered a word of warning that "these black Christians have little knowledge of Christianity and interact with gentiles. This means they easily return to rites that are not part of our faith." 78

Francisco Martín's arrival in Cartagena also tells a story of deep African connections, where enslaved and free Black individuals dwelling in the city

\footnotetext{
${ }^{74}$ AGN, SC, NE 43, legajo 13, doc. 9.

${ }^{75}$ AGN, SC, NE 43, legajo 13, doc. 9. fols. $3^{\mathrm{r}}, 38^{\mathrm{r}-\mathrm{v}}$.

${ }^{76}$ Havik, 2009 and 2012.

${ }^{77}$ Havik, 2009 and 2012; Splendiani, Sánchez Bohórquez, and Luque de Salazar, 2:35-459.

${ }^{78}$ Sandoval, 1627, BnF, LR, 4-O3C-6, fols. $38^{\mathrm{r}}-41^{\mathrm{r}}$.
} 
maintained knowledge and memories of Cacheu and Upper Guinea. As Martín's captors disembarked him from the ship, Martín reportedly encountered Pedro Bran. ${ }^{79}$ Bran, a free Black Christian who resided in Cartagena, testified to recognizing Martín, for he had previously dwelled in the same Portuguese captain's house where Martín had grown up in Cacheu. In that conversation-upon disembarking at Cartagena-Martín informed Bran that he was to be sold as a slave in the port. Bran reportedly expressed disbelief and told Martín that the latter could not be sold, for he was a free man. Another figure who purportedly recognized Martín as he disembarked from the ship was Sebastian Barroso, a thirty-year-old free mulato (Spanish term to denote person born to Black African and Spanish parents) and merchant (tratante) who resided in Cartagena. Barroso later explained that he had known Martín for sixteen years. He too claimed to have sojourned in the captain's house in Cacheu for six years a decade earlier, prior to Barroso traveling to Cartagena. Barroso and Bran were just two of seven free and enslaved Black African individuals who resided in Cartagena in 1614 and who testified - within three months of Martín's arrival-to knowing Martín as a freeborn person in Cacheu or on fleets across African coasts, prior to their arriving in Cartagena some years earlier. Some of the witnesses had been brought as slaves from Cacheu, while others reported that they traveled to the New World as free men or women. ${ }^{80}$

\section{LITIGATING FOR FREEDOM}

On 4 July 1614, one month after arriving in Cartagena, Francisco Martín presented a petition for freedom to the teniente general of Cartagena, Luis de Coronado, on the basis that his enslavement was illegitimate. ${ }^{81}$ Martín explained that he was a natural of Cacheu in Guinea and the son of Anton Martín, who was born in Cabo Verde, and his wife named Elena, who was of the Capi nation. Martín argued that he and his parents were "free [libres] and Christians" who lived in Cacheu in the house of a Portuguese captain. ${ }^{82}$ According to Martín's testimony, about eight and a half years earlier, in 1606, he had left Cacheu for Sierra Leone to labor as a wage-earning grumete on a ship for a Cacheu-based captain named Ambrosio Dias. After spending

${ }^{79}$ AGN, SC, NE 43, legajo 13, doc. 9, fols. $17^{\mathrm{r}}-26^{\mathrm{v}}$.

${ }^{80}$ AGN, SC, NE 43, legajo 13, doc. 9, fols. $17^{\mathrm{r}}-26^{\mathrm{V}}$. On free Black Africans who traveled (or labored) between Upper Guinea and West-Central Africa and the Americas, see Green, 2017; Ferreira, 203-48.

${ }^{81}$ AGN, SC, NE 43, legajo 13, doc. 9, fols. $3^{\mathrm{r}}-4^{\mathrm{r}}$.

${ }^{82}$ AGN, SC, NE 43, legajo 13, doc. 9, fol. $3^{\mathrm{r}}$. 
four years working as a grumete, Martín recalled how one day Dias sent him to the "beach of the sea" with a letter for a cleric named Manuel de Sossa. There on the shore they "tied my hands and put me on a ship and took me to Cacheu to the house of Juan Mendez." ${ }^{33}$ Martín recalled that Mendez had attempted to sell Martín to the same captain who had eventually brought Martín to Cartagena, named Antonio Rodriguez. According to Martín, Rodriguez had refused to purchase Martín since the captain knew that Martín was a free man. Thereafter, Mendez sold Martín to a Portuguese converso named Manuel Bautista Peréz who brought Martín to Cartagena on Rodriguez's ship along with his other enslaved cargo. It was only after arriving in Cartagena, Martín noted, that Bautista Pérez marked and branded his body with a hot iron to mark him as a slave. Martín pleaded that the Cartagena court recognize that "being free of free parents, and there not having been cause or title nor reason why for having been free and having been born free that I have come to this servitude," and asked that the court grant him freedom on the basis that his enslavement was illegitimate. ${ }^{84}$

A number of possibilities explain why the case was heard and eventually won, not just in Cartagena, but also on appeal in the higher court of the Audiencia de Santa Fe (in present-day Bogotá) the following year. The first possibility is a general concern in Cartagena that free Black Africans were being illegitimately enslaved in Africa. Francisco Gómez, Martín's legal defender, proposed such a possibility. ${ }^{85}$ Gómez noted that the practice of the unjust enslavement of Africans was infamous among residents in Cartagena. According to Gómez, it was widespread knowledge in Cartagena that slave traders often brought enslaved Africans to the port in "bad faith" as "[slave traders] trick free blacks and take them from their lands and bring them here to be sold as slaves." So endemic was the problem, he noted, that unjustly enslaved free Black Africans would proclaim their liberty "with loud voices [a voces]" as they disembarked from ships in Cartagena. Gómez elaborated that such Africans "arrive here shouting that they had been born free and that they are children of free parents and had come to a state of servitude." That act of shouting and using their voices to proclaim their liberty, explained Gómez, allowed Cartageneros to "know they are free," and that they had been unjustly enslaved, for such Africans "know how to proclaim their liberty." Noting legal precedent for Martín's litigation, Gómez referred to former legal cases in Cartagena courts in which unjustly enslaved Black Africans had pursued justice, of which he

${ }^{83}$ AGN, SC, NE 43, legajo 13, doc. 9, fols. $3^{\mathrm{r}}-4^{\mathrm{r}}$.

${ }^{84}$ AGN, SC, NE 43, legajo 13, doc. 9, fols. $3^{\mathrm{r}}-4^{\mathrm{r}}$.

${ }^{85}$ AGN, SC, NE 43, legajo 13 , doc. 9 , fols. $9^{\mathrm{v}}-10^{\mathrm{v}}$, and all further quotations in this paragraph. 
noted, "there are a great number in which they have been liberated as free." Gómez's argument is revealing: it suggests that there may have been fame and notoriety within Cartagena of the unjust enslavement of free Africans and that some Africans may have disembarked in Cartagena loudly proclaiming their freedom in Spanish or Portuguese, and more importantly, it suggests that similar litigations had been heard and won in the past. As I discuss below, Jesuit priest Alonso de Sandoval also recounted reading the transcripts of a litigation suit in Cartagena courts in which a Black man from Guinea tried to prove that he had been unjustly enslaved. ${ }^{86}$

Two historical conditions suggest that there may have been hushed discourses in Cartagena street corners about the legality of slavery with regard to just slavery and the possibilities for legal and extralegal routes to obtain freedom among Black city dwellers. First, in this period a number of cases emerged from Cartagena of enslaved Africans litigating for their freedom against their owners, not for unjust enslavement, but for undue harsh physical violence. ${ }^{87}$ Second, the presence of palenques (a community of fugitive Black enslaved subjects who escaped bondage and formed a Maroon community) in the hinterlands and the seemingly fairly common aspiration-as documented by Larissa Brewer-García, Jane G. Landers, Kathryn J. McKnight, and María Cristina Navarrete Peláez-among enslaved Black city dwellers to flee in search of freedom to established palenques. ${ }^{88}$ These scholars have explored how royal officials' interviews with former residents of the Palenque del Limón and the Matudere Palenque-two Maroon communities that Cartagena officials destroyed in 1634 and 1693, respectively—shed light on the emergence and circulation of alternative ideas about governance and freedom among enslaved and free Black individuals in seventeenth-century Cartagena. Such ideas often disregarded legal structures of justice and involved collective acts of resistance. Conspiracies among Black populations to escape enslavement and join palenques are one such example. In particular, these scholars have traced the ties that residents of palenques in the hinterlands often maintained with Black port dwellers in Cartagena, suggesting a constant circulation of information and ideas about alternative and illicit forms of governance and means to obtain freedom.

Martín's ability to command free and enslaved Black witnesses who claimed to know him from Cacheu attests to the existence of discourses about legal and extralegal means of evading slavery in Cartagena. Certainly, Martín's owner Manuel Bautista Pérez posited exactly that theory in the trial; he claimed

\footnotetext{
${ }^{86}$ Sandoval, 1627, BnF, LR, 4-O3C-6, book 1, chapter 7, fols. $65^{\mathrm{r}}-70^{\mathrm{v}}$.

${ }^{87}$ For example, AGN, SC, NE 43, legajo 9, doc. 1. See also Navarrete Peláez, 2017, 16-19.

${ }^{88}$ Brewer-García; Landers; Navarrete Peláez, 2003 and 2015; McKnight.
} 
that it was well known in the city that "the blacks conspire to free one another by providing false testimonies." ${ }^{89}$ Further, upon arriving in Cartagena de Indias, Martín dwelled in a house in the town with his owner, Bautista Pérez, and with at least two other enslaved Africans, who may or may not have arrived with Martín on the slave ship. As criminal trials and other Black Cartageneros' freedom suits of the period demonstrate, city dwellers were often intimately connected to the business and affairs of their neighbors. ${ }^{90}$ Word of Martín's litigation might have spread rapidly among Black residents in the port. Certainly, in the house where Bautista Pérez resided, Martín would have had daily relationships with other servants and slaves and with other neighborhood residents, with the exception of the times that Bautista Pérez restricted Martín's movements by incarcerating him in chains and imposing life-threatening physical injuries. ${ }^{91}$ Perhaps such daily interactions-even if infrequent due to Bautista Pérez's harsh violence and imprisonments of his captive-are how Martín gathered his witnesses.

There is another important element that affected broader discourses in Cartagena about just slavery and, in turn, shaped the outcome of the case. When Martín commenced to litigate for his freedom, he did so in a city engrossed in debates on just slavery, especially among Jesuits. ${ }^{92}$ For example, Alonso de Sandoval dwelt on the matter throughout his treatise Naturaleza, policia sagrada i profana, costumbres $i$ ritos, disciplina i catechismo evangelico de todos Etiopes (The nature, sacred and profane government, customs and rites, and discipline and evangelical catechism of all Ethiopians, 1627), and he also dedicated an entire chapter to the question of the justness of the enslavement of Black Africans. ${ }^{93}$ As Sandoval explained, "the debate among scholars on how to justify the arduous and difficult business of slavery has perplexed me for a long time." 94 Sandoval described how different slave traders had approached him in Cartagena to seek his counsel on whether their slave trading was legitimate and moral, as they doubted whether the Africans that they had brought to the Indies had been justly enslaved. Sandoval recounted how "a captain who owned slave ships that made many voyages to those places [Sao Tome]" and who had enriched himself, found that "his conscience was burdened with concern over

${ }^{89}$ AGN, SC, NE 43, legajo 13, doc. 9, fol. $39^{\mathrm{r}-\mathrm{v}}$.

${ }^{90}$ AGN, SC, NE 43, legajo 9, doc. 1; legajo 10, doc. 9.

${ }^{91}$ AGN, SC, NE 43, legajo 13, doc. 9, fols. $7^{\mathrm{v}}-16^{\mathrm{r}}$.

${ }^{92}$ Cárdenas; Vignaux, 33-83.

${ }^{93}$ Sandoval, 1627, BnF, LR, 4-O3C-6, fols. $65^{\mathrm{r}}-70^{\mathrm{v}}$. See also Cárdenas; Sandoval, 2008, $50-55$.

${ }^{94}$ Sandoval, $1627, \mathrm{BnF}, \mathrm{LR}, 4-\mathrm{O} 3 \mathrm{C}-6$, fols. $65^{\mathrm{r}}-70^{\mathrm{v}}$, and all further quotations in this paragraph; translations in this paragraph are by Nicole von Germeten, in Sandoval, 2008, 50-55. 
how these slaves had fallen into his hands." The captain reported to Sandoval his discomfort with how "one of their kings imprisoned anyone who angered the king in order to sell them as slaves to the Spaniards." Another slave-ship captain confided in Sandoval, "Father, I go to Angola to buy blacks. This is a dangerous and expensive voyage. When I leave, after having spent a great deal on the slaves, I feel guilty. I ask myself, am I satisfied with how slavery is justified?. . . What if I bring them to live the rest of their lives in Christian lands, but they never become Christian?" Sandoval's concern for the justness of the enslavement of Black Africans led him to conduct interviews with slave traders, captains, free and enslaved Africans, priests, and officials in Cartagena de Indias, while he also engaged in correspondence with Jesuits in Luanda and Sao Tome to inquire about their views on the legitimacy of enslaving Africans; and, importantly he reviewed legal cases from Cartagena courts-akin to Francisco Martín's-in which Africans argued that they had been unjustly enslaved in Africa. Echoing Francisco Martín's litigation, Sandoval reported the transcript of a legal case that he had consulted in which a Black man from Guinea was trying to prove that he was legally free in Cartagena courts. Surveying the case, Sandoval noted, "although it could be proved that he was legally a slave, he could not prove his freedom."

Sandoval's theological reasoning for the enslavement of Black Africans is significant for the close parallels with Francisco Martín's and his African witnesses' legal arguments in positioning Africans as Christians. Early seventeenth-century Cartagena de Indias lay at the heart of a Jesuit project to establish an elected Black church, spearheaded by Alonso de Sandoval. He sought to represent all Africans as ancient Ethiopian Christians of God's first church who had guided the rest of the nations toward Christianity. ${ }^{95}$ Throughout the treatise, however, Sandoval described how Ethiopians' ancient Christianity had decayed in Africa. According to Sandoval, only through slavery and religious guidance in the New World (under the watchful eye of the Jesuits) would Africans be restored to a glorious Ethiopian past. ${ }^{96}$ In short, Sandoval positioned all Black Africans as corrupted Ethiopian Christians and believed that a universal elected Black church would be established in the New World through the enslavement, baptism, and religious guidance of Black Africans. Sandoval thus reductively

${ }^{95}$ Sandoval, 1627, BnF, LR, 4-O3C-6, book 2, chapter 6, fols. $147^{\mathrm{r}}-150^{\mathrm{r}}$; chapter 8, fol. $153^{\mathrm{r}-\mathrm{v}}$. I explore Sandoval's ideas about the legitimacy of enslaving Black Africans and Ethiopian Christians in a forthcoming article, "Imagining Ethiopia in the Early Hispanic Atlantic: Revisiting Blackness, Purity of Blood, and Just Slavery through Alonso de Sandoval's Catechismo Evangelico de todos Etiopes," which is due to appear in Revue d'histoire modernre et contemporaine in 2021.

${ }^{96}$ Sandoval, 1627, BnF, LR, 4-O3C-6, book 1, chapter 32, fols. $128^{\mathrm{v}}-130^{\mathrm{v}}$. 
described the entirety of Africa as the site of a lost Ethiopian church, which enabled him to argue for the just enslavement of all Black Africans (as lost Christians) on the basis that the experience of slavery would lead them back to their original Christianity. This line of reasoning - and the broader discussions in Cartagena that Sandoval reported — might point toward Cartagena as a particularly acute site for discussions of just and unjust enslavement of Black Africans.

Importantly, Francisco Martín's reasoning for his unjust enslavement was not diametrically opposed to Sandoval's. Martín and his procurador Francisco Gómez were arguing that Sandoval's logic of enslavement did not apply to people like Martín who came from already established Christian communities in Africa. In their litigation, Gómez and Martín presented a biting argument as to the illegality of enslaving "between Christians." 97 Gómez argued that even "in the case that [Martín] had been sold one hundred times," such an occurrence "could not harm his natural right" to freedom because Martín was the "son of free parents and he has been brought up and lived as a free man, and it is not legal [no consta, ni puede constar] that he [Francisco Martín] has become enslaved [cautivo] in a just war, or even an unjust war, nor that he has been sold by his parents, nor [enslaved as punishment] for a crime that he might have committed because there is no right [no hay derecho] to enslave between Christians for any of these reasons." In short, Sandoval argued that the enslavement of lost or corrupted Christian Africans was justified in order to lead them back to Christianity, while Martín never disputed the legitimate enslavement of non-Christians or those whose Christianity had decayed over the generations: his and his witnesses' arguments relied on the fact that such a circumstance did not apply to Martín since he was already a Christian in Cacheu, and that it was illegal to enslave a Christian for any reason.

In the year and a half (if not longer) that Francisco Martín spent languishing in Cartagena de Indias between June 1614 and November 1615, while he litigated for his freedom, living between his owner's house in the city, the public jail, and in protective custody, it is likely that Martín would have encountered or at least heard of the Jesuit fathers and their interest in the just enslavement, baptism, and religious education of Black Africans. This is because although the Jesuit mission in Cartagena was relatively small at the beginning of the seventeenth century-Alonso de Sandoval commenced his ministry there in 1606, and by 1611 the Jesuit mission comprised just six fathers and five brothersthis handful of Jesuits regarded themselves at the center of the Black population in Cartagena. ${ }^{98}$ Jesuits claimed in their letters to Rome that almost every

${ }^{97}$ AGN, SC, NE 43, legajo 13, doc. 9, fol. $10^{\mathrm{r}}$, and all further quotations in this paragraph.

${ }^{98}$ Brewer-García, 83-130; Navarrete Peláez, 2009. 
enslaved and free Black person who resided in Cartagena would choose to hold their confessions and final death rites with one of the Jesuits, while the company would reportedly preach to two thousand to three thousand Black port dwellers who would gather for Mass on Sundays. ${ }^{99}$ It is likely that Francisco Martín would have developed an awareness of the Jesuits' presence in the city, and their ongoing investigations into questions of just slavery and African Christianity. Martín and his witnesses deployed knowledge from Cacheu and elsewhere in their legal strategy, while also operating in an intellectual climate in Cartagena that permitted the possibility of imagining Black Africans as Christians.

\section{UNJUST SLAVERY}

A coterie of Black and mulato witnesses from Africa (and one from Portugal), who resided in Cartagena either in captivity or as free individuals, testified to knowing Martín in Guinea and communicating with him in Cartagena in the three months since his arrival (witness testimonies were presented in late August 1614). These witness statements demonstrate the existence of a discourse among Black port dwellers pertaining to African Christianity and the legitimacy of slavery. The Black witnesses argued that Martín's enslavement was illegitimate because he was a free African Christian. ${ }^{100}$

Aforementioned forty-five-year-old Pedro de Tierra Bran, for example, who described himself as a free Black Christian, explained that he knew Francisco Martín from Guinea. Before Bran had traveled to Cartagena seven years earlier, he had spent fifteen years residing in Cacheu and had worked as a servant in the house of a Portuguese captain. There, Bran had seen Martín living with his parents-both free Christians - and described how he saw them "have and possess their liberty." Bran explained that Martín had labored on ships in Tierra de Zoala and in Tierra de Cape, serving "white masters" who treated and paid him as a "free person born to free parents." A fifty-six-year-old free mulato named Domingo Morrera, a resident of Cartagena who was born in Tavila (Portugal), recalled that when he labored as a pilot in Guinea some twelve or thirteen years prior, he had worked alongside Martín on a ship in Cacheu. On that ship, Morrera recounted that he saw Martín laboring for a wage as a

\footnotetext{
${ }^{99}$ Navarrete Peláez, 2009, 42-43. See also the letter from Alonso de Sandoval to his superior on 5 October 1612 about the final death rites for a free Black woman who owned property and slaves, quoted in Vignaux, 390n478. This is supported by the testimonies in Pedro Claver's beatification process: see Splendiani and Aristizábal Giraldo.

${ }^{100}$ AGN, SC, NE 43, legajo 13, doc. 9, fols. $17^{\mathrm{r}}-26^{\mathrm{v}}$, and all further quotations in next two paragraphs.
} 
grumete and that the entire crew considered Martín to be a free person. Francisco from Cabo Verde, who was enslaved to a ship captain in Cartagena, explained that he knew both Francisco Martín and Manuel Bautista Pérez. Francisco had had been forcibly displaced through slavery from Guinea to Cartagena eight years earlier and testified that he had known Martín for six or seven years from when he lived in Cacheu. Francisco stated that he had been brought up in those lands, and thus had known Martín since he was very young and had seen Martín living in the captain's house, "always seeing that he lived and was reputed as a free man." Francisco added that he would have heard if Martín had been enslaved because "the land of Cacheu is very short," implying perhaps that news of residents' lives traveled fast.

A key question regarding unjust slavery posed by Martín concerned on which side of the Atlantic Ocean the physical branding of his body to signify his status as a slave had taken place. According to Martín, it was only upon arriving in Cartagena and hearing that Martín might litigate for his freedom, that Bautista Pérez had branded his slave's chest with a hot iron. Three of Martín's witnesses attested that the branding occurred in Cartagena and not in Guinea. Sebastian Barroso explained that Francisco Martín was not branded when he disembarked from the ship, but that a few days later he saw Martín with a "mark of fire on his chest." Martín's seven witnesses attested to the common practice of slave traders branding captives in Guinea prior to embarking slaves on ships and assured the court that slave traders were prohibited in Guinea from branding free Christian Africans as slaves. Another witness named Manuel, who had testified that he had been brought as a slave from Cacheu to Guinea some years earlier, explained that he knew that slaves were branded in Guinea because he himself had been branded there prior to being brought as a captive to Cartagena, and that correspondingly, he knew that "they did not brand free people there [Guinea]."

Manuel Bautista Pérez refuted Martín's claims to illegitimate enslavement. Bautista Pérez explained that Martín had previously been a captive to many other Portuguese traders in Guinea, and that he had purchased Martín from a Portuguese slave trader based in Cacheu named Juan Méndez Mezquita in payment of 150 pesos that Méndez Mezquita owed Bautista Pérez. ${ }^{101}$ Bautista Pérez argued that Martín's litigation in Cartagena was calculated. Sufficient structures of justice existed in Cacheu, argued the irate slave owner, for Martín to have pursued his freedom there, had he believed that his former masters had unjustly enslaved him. Bautista Pérez's witnesses confirmed that courts where enslaved Africans could seek such justice indeed

${ }^{101}$ AGN, SC, NE 43, legajo 13, doc. 9, fols. $27^{\mathrm{r}}-36^{\mathrm{v}}$, and all further quotations in this and next paragraph. 
existed in Cacheu and reported that other free Black individuals in the Guinean port would litigate for their freedom when unjustly enslaved. Bautista Pérez also denied that Martín had been branded in Cartagena, instead asserting that Martín had been branded in Cacheu. The slave trader's witnesses also confirmed Bautista Pérez's assertion that he had branded Martín "with the rest of his Blacks" in Cacheu.

Bautista Pérez also questioned the legitimacy and credibility of Martín's Black witnesses. On 29 September 1614-one month after Martín presented his witnesses- Bautista Pérez argued that his case was stronger because his witnesses were honorable men of great faith and credit who had resided in Guinea and the port of Cacheu for many years. In contrast, Bautista Pérez argued, Martín had not proven anything because his Black and mulato witnesses "have no faith or credit." Bautista Pérez alluded to widespread notoriety in Cartagena that because these Black Africans were of the same nation, "they say untruths and they are ignorant people who do not understand their juramento [oath] because of their incapacity." Finally, Bautista Pérez suggested that a conspiracy existed among Black dwellers of Cartagena to help each other obtain freedom by providing false witness testimonies.

After the court ruled in Martín's favor in November 1614, pronouncing him as a free man who had been unjustly enslaved, Bautista Pérez presented an appeal in which he transformed the legal argument from a debate about just enslavement on the basis of Christianity or lack thereof, to a juridical argument concerning just war and rescate. ${ }^{102}$ On appeal, in November 1614, Bautista Pérez recalled that two and a half years prior, Martín had labored as a grumete on a ship owned by Cacheu-based Juan Méndez Mezquita. The crew comprised Black and white laborers who were tasked with rescuing Black slaves who had been taken captive by negros de guerra (Blacks of war), a term that Bautista Pérez defined as groups of Black Africans who would "spend their time waylaying and robbing ships" on the coasts of Guinea to steal merchandise and ransom any enslaved Africans and crew on the ships back to European merchants. Bautista Pérez explained that during the expedition, the negros de guerra overpowered Méndez Mezquita's ship, killing the captain and pilot and imprisoning the white and Black sailors, and enslaving the Black slaves and free men alike. It was in this moment, Bautista Pérez argued, when Martín became enslaved in a just war at the hands of the negros de guerra. According to Bautista Pérez, a Cacheu resident named Enriquez Hernández rescued the captured ship and crew and negotiated the ransom price that would ensure the release of the captives. From that point onward, Bautista Pérez posited, Martín was a slave of just

${ }^{102}$ AGN, SC, NE 43, legajo 13, doc. 9, fols. $41^{\mathrm{r}}-54^{\mathrm{r}}$, and all further quotations in this paragraph. 
war, and was thus legitimately enslaved, since he had been the subject of a legitimate rescate. Further, it was Martín's previous employer, Juan Méndez Mezquita, who provided Hernández with the purchase price of 150 pesos for Martín's release, meaning that ownership of Martín transferred to Méndez Mezquita. Thereafter, Bautista Pérez explained, Martín served as a slave in Méndez Mezquita's household in Cacheu—that is, until Méndez Mezquita sold Martín to Bautista Pérez. Bautista Pérez thus argued on appeal that Martín had been enslaved in a just war in Africa, captured by Black Africans and subsequently purchased by Europeans in a legitimate rescate.

The legal arguments presented in the case therefore transformed from a discussion of unjust enslavement of African Christians to the legitimacy of slavery through just war and rescate. All the while, Martín and his witnesses stood their ground and argued that as a free Black African Christian, he could not be enslaved. Responding to the appeal on 20 February 1615, Martín agreed that he had indeed labored as a grumete for Juan Méndez Mezquita, but noted that he had done so as a free man who earned a salary "like the other free people." 103 $\mathrm{He}$ also testified that one day some negros de guerra captured the entire ship. Martín explained how they killed the captain and the pilot and tied up the remaining enslaved cargo and the free Black and white laborers onboard the vessel. However, Martín refuted that the capture of the Portuguese ship by the negros de guerra meant that a just war had taken place. Martín agreed that Hernández paid a ransom for him and the crew but denied that he had been enslaved. Instead, Martín explained how upon returning to Cacheu, he and Juan Méndez Mezquita signed a contract specifying that Martín would labor for him as a grumete for two more years. Martín explained how thereafter, one time, while traveling toward Gambia, he managed to escape an English raid in a town where he was based and had returned to Méndez Mezquita's abode in Cacheu. Thus, even when Martín acknowledged that he had been captured by negros de guerra and was subsequently freed through a ransom paid by a Portuguese merchant, he positioned such an event in terms of his capture and rescue alongside other free white sailors. He argued that he agreed to continue laboring for Méndez Mezquita, but with a time-specified labor contract as a wage-earning grumete.

\section{THE CROWN'S DOUBT ON JUST SLAVERY}

The ruling by Luis de Coronado, the teniente general of Cartagena, on 22 November 1614 that Martín was "free and not subject to captivity or servitude," along with the order that Manuel Bautista Pérez allow Martín "to

${ }^{103}$ AGN, SC, NE 43, legajo 13, doc. 9, fols. $54^{\mathrm{r}}-56^{\mathrm{r}}$. 
enjoy [gozar] his liberty" without imposing any impediments, is especially surprising because of the weight that it gave to Martín's Black African witnesses over those presented by Bautista Pérez. ${ }^{104}$ In Cartagena, like in Guinea, Bautista Pérez interacted with trading associates who were part of his extended network of New Christian Portuguese diaspora. ${ }^{105}$ Indeed, the witnesses who on 7 July 1614 attested to Bautista's ownership of Martín were slave traders poised to depart from Cartagena to Spain. ${ }^{106}$ All six witnesses were vecinos of Portugal. Bautista Pérez's witnesses testified that that they had spent time in the port of Cacheu during the previous decade and knew Martín in Cacheu, while agreeing that Bautista Pérez was an honorable man of Christian faith who would never purchase a free man.

Coronado's ruling and favoring of the testimonies provided by enslaved and free Africans in Cartagena suggests that debates and doubts regarding just slavery existed among royal deputies in Cartagena de Indias. Coronado's decision also paralleled the legal precedents described by Francisco Gómez, who had stated that many similar legal cases regarding illegitimate enslavements had been previously heard in Cartagena courts and had resulted in the courts setting litigants free. ${ }^{107}$ The ruling also dismissed a request that Bautista Pérez had made to present evidence that Martín's witnesses were unreliable, untrustworthy, and reputed as drunks, and were engaged in a conspiracy in Cartagena to free enslaved Black Africans. Similarly, Bautista's appeal based on just war and legitimate rescate failed. On 17 March 1615, Luis de Coronado decreed that his initial ruling, in which he had freed Martín, was final. ${ }^{108}$ Coronado referred the case to the Audiencia de Santa Fe for final sentencing and ordered both parties, or their representatives, to appear in that court four months later. The Audiencia de Santa Fe considered the case on 7 July 1615, and by 13 November 1615 the court reiterated Luis de Coronado's ruling of 28 November 1614, with the added clause that Martín should serve the person who paid for his ransom for a year, thereby both confirming Martín's freedom while potentially subjecting him to another year of servitude to Bautista Pérez (although the ruling is ambiguous as to whether Martín had already served the year). ${ }^{109}$ By 10 May 1616-nearly two years after Martín initiated his petition in July 1614 - the Audiencia asked for both parties to be notified of the final decision.

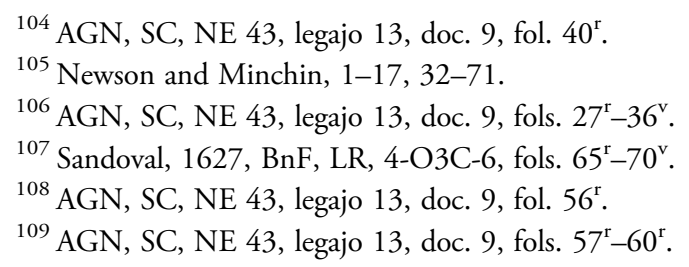


These rulings point to the Crown's concern regarding the unjust enslavement of Black African Christians. Coronado's ruling in Martín's favor and the confirmation of his opinion on appeal by the court in Santa Fe suggests that some doubt existed among judges in royal courts as to the just enslavement of African Christians. As Martín's procurador noted, Martín was so poor and naked that he had nothing to offer these witnesses for their testimonies, and presumably also lacked any financial means to fund a legal petition. Such a situation implies that the Crown also had a legal structure in place to allow for individuals who might have been free African Christians to petition for justice on the basis of unjust enslavement. Coronado's ruling to free Martín suggests that the Crown harbored an element of doubt over the just enslavement of some Black Africans, at least when responding to individual petitions. And the existence of that official doubt explains why the credibility of the African witnesses trumped the credibility of Bautista Perrez and his wealthy merchant associates. Coronado's ruling, in addition to Bautista's failed appeal and the final decision in the Santa Fe courts, points toward a broader discourse in the courts about African Christians and the rule of law regarding just slavery.

\section{LEGAL FREEDOM, TORTUROUS EXISTENCE}

A reflection on the significance of Martín's litigation in his lived experience, regardless of any legal pronouncements of his freedom, suggests limits to the power of discourses on unjust slavery based on Christian origins for many Africans. As many scholars before me have pointed out, legal pronouncements of freedom-whether in a court or an owner's will—did not necessarily correlate to a lived reality of freedom as specified by the law. There is a contrast between a legal pronouncement of freedom and the often-violent lived reality of partial or nonexistent freedoms. In a study on seventeenth-century Lima, Michelle A. McKinley examined how enslaved Black women litigated in ecclesiastical courts, not for their entire freedom, but for small fractions of their freedom, such as the right to choose their owner, to marry, to live semiindependently, or to purchase their freedom at a later date. ${ }^{110}$ In Francisco Martín's case, he did not litigate for a fractional freedom, but for his entire freedom, and yet it is likely that any freedom that he did obtain may have indeed been fractional.

A disjuncture emerged between Martín's lived experience of partial, fractional, or inexistent freedom and the legal freedom specified by the court, at least in the months following the Cartagena court's ruling. Martín did not obtain any semblance of liberty in the first few months after the Cartagena

\footnotetext{
${ }^{110}$ McKinley, 1-73.
} 
court's ruling, for he remained imprisoned in the public jail and in his owner's residence, in spite of a legal ruling that liberated him from slavery. When Martín was interviewed in early March 1615 for Bautista's appeal-three months after the ruling that supposedly freed him from slavery-Martín was languishing in the public jail. ${ }^{111}$ By 26 March 1615, he had been transferred to Bautista's residence. On that date, Martín's procurador and a court scribe certified in sworn statements that Bautista had imprisoned Martín in chains. Thus, the legal pronouncement of Martín's freedom in November 1614 did not translate to a lived experience of freedom, at least not initially. Further, Martín's transfer between the public jail and Bautista's home in March 1615 suggests an extralegal corruption in due process, since the court had ordered that Martín be given his liberty. The final decision by the court in Santa Fe supposedly guaranteed that Martín would become free within a year. But after the Audiencia de Santa Fe's ruling_-if Martín did indeed have to serve Bautista for another year-it is possible that Bautista Pérez might have attempted to sell Martín, whom he perceived as his disobedient captive. In such a scenario, Martín likely would have endured another arduous and violent process of litigation for his freedom in a different court, wherever his new owner happened to be located.

The stakes for litigating for freedom were severe; Martín suffered horrific violence and imprisonment at the hands of his owner in retribution for seeking his freedom in the courts. On 5 July 1614, the day following Martín's initial appeal, Gómez complained that upon hearing of Martín's plight for freedom, Bautista Pérez had grabbed Martín and "giving him many beatings [porrazos]," had taken Martín to the jail, and later that afternoon had transferred the captive to his house and tied Martín in chains, giving "him many bad treatments." $112 \mathrm{~A}$ month later, Gómez complained that Bautista Pérez violently and loudly whipped Martín late into the nights in retribution for Martín's litigation. Black enslaved neighbors who resided on the same street as Bautista Pérez in Cartagena testified that they would hear the sound of whipping and shouting late into the evenings and Martín's cries in the mornings, while also seeing the visible injuries on Martín's body on the days following the audible tortures. Bautista Pérez also imprisoned Martín by locking him in chains in the house, apparently in an attempt to prevent him from engaging with the Black population of Cartagena to locate witnesses. Martín's procurador complained to the courts that Bautista Pérez's imprisonment of Martín—with cuffs (grillos) chained to his feet-rendered the litigator unable to show the procurador his

${ }^{111}$ AGN, SC, NE 43, legajo 13, doc. 9, fols. $54^{\mathrm{r}}-56^{\mathrm{r}}$.

${ }^{112}$ AGN, SC, NE 43, legajo 13, doc. 9 , fols. $7^{\mathrm{v}}-16^{\mathrm{r}}$, and all further quotations in this and next paragraph. 
witnesses and asked that the court order that Martín be permitted to freely go about his business for his litigation. It was not until 28 July 1614, three weeks after the initial petition, that the court ordered for Martín to be forcibly removed from Bautista Pérez and placed in protective custody.

The supposed reprise from the violence was short-lived, though. Bautista Pérez's rebuttal led the court to order that Martín be returned to his owner three days later. Bautista Pérez attested that the whipping served as a punishment, not for Martín's litigation, but for Martín committing a robbery and disobeying his owner. Bautista Pérez posited that Martín had stolen some corn from him on behalf of Agustin Moreno, who was known as the "captain of the blacks in Cartagena." By 3 August 1614, a month after legal proceedings had commenced, Gómez explained that Bautista had whipped Martín so harshly that the litigant was bedridden and could not leave the house. Martín thus suffered severe physical violence in the month after he initiated litigation for his freedom. Considering the threat of violence and reprisals that participation in such a trial might entail, especially for those who were enslaved, but also for free Black city dwellers and those involved-even if just peripherally_in the slave trade (such as, for example, the free mulato trader Sebastian Barroso and the free mulato ship pilot Domingo Morrera), the testimonies that Martín's witnesses provided are striking, especially their reflections on definitions of just slavery.

Francisco Martín's fate and whether he ever regained his freedom remains unclear; he disappears from the archival record after the May 1616 pronouncement in the Santa Fe court of his one-year-delayed liberty. Had Martín remained in Bautista Pérez's power for another year, there is little doubt that he would have been subjected to continued violence. Martín might also have found himself onboard another voyage to Guinea, as Manuel Bautista Pérez left Cartagena for Portugal soon after the ruling-or perhaps earlier-to prepare for a second journey to Cacheu. In 1615, Bautista purchased 280 slave licenses at the House of Trade in Seville in order to prepare for his next slave-trading expedition to Guinea. ${ }^{113}$ By 25 November 1616, Bautista—or someone whom he empowered — signed a contract with his uncle and mentor Diogo Rodrigues in Lisbon to specify the upcoming slave purchases, goods to be sold in Cacheu, and shares of profits.

Over the next decade, Bautista Peréz became one of the wealthiest merchants in Lima. After his second trip to Cacheu, he returned to Cartagena and thereafter established himself in Lima in 1619. In Lima, Bautista Pérez organized yearly shipments of slaves from Cartagena. As Linda Newson and Susie Minchin describe, Bautista Pérez "traveled to Cartagena personally to acquire

${ }^{113}$ Newson and Minchin, 16-22. 
slaves [until 1623], but thereafter relied on agents who were based there, notably Sebastian Duarte," his brother in law. ${ }^{114}$ During the 1620s and 1630s, Bautista "was shipping between 150 and 500 slaves a year from Cartagena to Peru." 115 Historian Irene Silverblatt describes how Bautista Pérez dominated the slave trade by the 1630s and became one of the colony's wealthiest subjects and a powerful merchant in international commerce. ${ }^{16}$ Historian Toby Green has also uncovered that Bautista Pérez maintained familial ties in Cacheu while residing in Lima; he wrote letters to his daughter in Cacheu, who was born to a West African mother, and would send her money. ${ }^{117}$ Bautista Pérez's downfall came at the height of his wealth and influence, when Inquisitors, who were investigating the lives of New Christian Lima residents, focused their attention on one of the most prosperous of the Portuguese New Christian merchants of the city, Manuel Bautista Pérez. In 1635, the Inquisition of Lima arrested Bautista Pérez and accused him of being the leader of Peru's secret Jews, and sentenced him to death in $1639 .{ }^{118}$

Martín's case is therefore an important reminder of the ambiguities of justice in this period. While he was able to access the courts and successfully litigate against his unjust enslavement on the basis of the illegitimacy of enslaving between Christians, and win the case in the first instance, and on appeal, and again in the Audiencia de Santa Fe, he suffered severe violent reprisals for his litigation at the hands of his owner. Importantly, it remains unclear whether he ever lived as a free man after his successful litigation for freedom that reached the highest court in the New Kingdom of Granada.

\section{DISCOURSES OF AFRICAN CHRISTIANITY AND OF JUST AND UNJUST SLAVERY}

Francisco Martín's and Domingo Gelofe's freedom litigation suits suggest that enslaved Africans who positioned themselves as African Christians in legal cases in the Spanish Empire did not engage in discourses of just slavery and Iberian law in an intellectual vacuum. They did so in port cities where discussions about the morality and legality of the enslavement of Africans were ongoing, in part propelled by theologians such as Cartagena-based Jesuits whose interests in just slavery stemmed from their mission to baptize African slaves and for the establishment of a Black elected church in that city, and in part by knowledge of

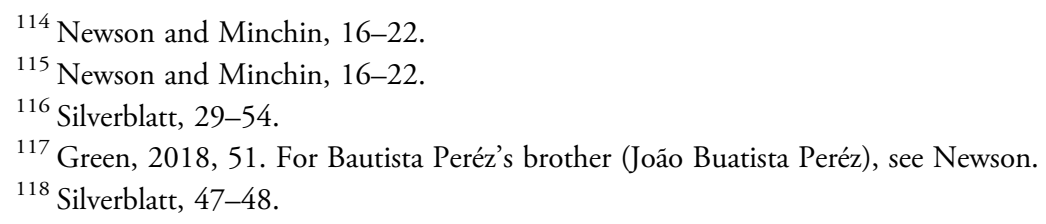


legitimate and illegitimate slavery obtained in the sites where they had resided in Upper Guinea and West-Central Africa. The Black Catholicism presented in such cases sidestepped or even embraced traditional or radical discourses of just war. The legal strategy of these Black Africans was to double down on Old Christian identities. There is a great distinction to this strategy and that available to Indigenous Americans, which relied on a notion of a people who had no knowledge of Christianity before contact with Iberians. Jesuit theologian Alonso de Sandoval's pro-slavery manifesto and enslaved Francisco Martín's arguments as to his unjust enslavement were not distinct-both recognized African Christianity and the illegitimacy of enslaving African Christians. Francisco Martín and his witnesses were deeply embedded in contemporaneous Iberian concerns about baptism and Christianity that troubled Sandoval; they simply argued that it did not apply in Martín's case because he was in fact already a Christian.

Discourses among theologians and enslaved Africans were connected through the urban landscapes where they resided. For this intellectual history to make any sense, the entanglements under discussion cannot just be spatial (between Cartagena, Cacheu, and Sierra Leone or between Gelofe, Tenerife, on fleets that crossed the Atlantic, and Seville), but also between different discursive registers within the same urban spaces that include (but are not limited to) legal strategies, sermons, word of mouth, and theological treatises. In other words, these spheres of social and intellectual history were connected. As Sandoval described, he consulted the transcripts of litigation suits for freedom from Cartagena in order to read and understand the arguments presented by enslaved Africans pertaining to their unjust enslavement, and such arguments—or the cases more broadly_inevitably informed some of his own theological thinking on the just enslavement of Africans. Additionally, theologians' discourses about an ancient African Christianity that sought to legitimize the just enslavement of all Black Africans permitted Black individuals to shape legal discourses of their unjust enslavement in the courts. The Jesuits developed in Cartagena a legal culture of credibility regarding African Christianity that inadvertently allowed enslaved Black individuals to litigate for their freedom as Christians, mobilize witnesses, and, sometimes, to obtain pronouncements of their liberty in royal courts, even when pitted against influential and wealthy slave owners. This intellectual history of just and unjust slavery thus highlights the important entanglement of ideas between groups with vastly different vested interests, who inhabited — sometimes in close quarters- the same urban spaces, and between individuals who traversed the ocean either freely or as enslaved captives and met one another in different ports along the way.

This exploration of enslaved Africans' impact on the discursive landscapes of the cities where they resided begins to position Black Africans 
historiographically as important actors in the intellectual history of the Atlantic world, in this particular case, within discourses of unjust slavery. Focusing on petitions for relief from the courts on the basis of unjust enslavement, this article is emphatically not arguing that enslaved Black Africans contributed to a discourse that justified their own enslavement. Instead, the existence of this history in the colonial archive exemplifies the limited strategies that were available to enslaved Africans to seek their freedom in Castilian colonial society. This intellectual history entered the archives because these legal strategies spoke to Iberian monarchs' concerns about the potential illegitimacy of enslaving African Christians, a concern that permitted the possibility that some courts might hear the cases of enslaved litigants who presented these arguments. Other forms of resistance remain silent to historians, for they did not enter the colonial archive. The legal strategy of arguing for unjust enslavement on the basis of a prior Christian faith and freedom in Africa responded to the available Iberian legal mechanisms and decisionmaking in certain locales of the late sixteenth and early seventeenth century. It was a strategy employed by a few in a desperate attempt to gain freedom from a torturous existence. 


\section{BIBLIOGRAPHY}

\section{Archival and Manuscript Sources}

Archivo General de la Nación de Colombia, Bogotá (AGN), Sección Colonia (SC), Negros y Esclavos (NE) 43: legajo 9, documento 1, "pleito con Juana, su negra esclava; quien pedía carta de libertad," 1634; legajo 10, documento 9, "Francisco de Segura, mulato," 1611; legajo 13, documento 9, "Pleito de liberación," 1615.

Archivo General de las Indias, Seville (AGI), Contratación (Cont.), 5536, Libro de Asientos de Pasajeros a Indias: 1. 1-5. 1509-40.

AGI, Indiferente (Ind.), 416, 1. 3, fols. $19^{\mathrm{r}-\mathrm{v}}, 23^{\mathrm{v}}, 34^{\mathrm{v}}-35^{\mathrm{r}}$. Documents pertaining to Diego Ordás's armada. 1530.

AGI, Ind., 422, 1. 17, fols. $114^{\mathrm{r}}-115^{\mathrm{r}}$. "Real Cedula, Domingo, cristiano, natural de Gelofe." 1537.

AGI, Ind., 1205, no. 21. "Petición, Domingo de color negro." 1536.

AGI, Justicia, 712, no. 1. "Alvaro de Ordás contra Francisco Verdugo." 1535-37.

\section{Printed Sources}

Alencastro, Luiz Felipe de. "Portuguese Missionaries and Early Modern Antislavery and Proslavery Thought." In Slavery and Antislavery in Spain's Atlantic Empire, ed. Josep M. Fradera and Christopher Schmidt-Nowara, 43-73. New York: Berghahn, 2013.

Almorza Hidalgo, Amelia. "Género, emigración y movilidad social en la expansión Atlántica: Mujeres españolas en el Perú colonial (1550-1650).” Tiempos Modernos: Revista Electrónica de Historia Moderna 8.29 (2014): 1-3.

al-Musawi, Muhsin J. The Medieval Islamic Republic of Letters: Arabic Knowledge Construction. Notre Dame, IN: University of Notre Dame Press, 2015.

Bartolomé de Las Casas: Face à l'esclavage des Noir-e-s en Amériques/Caraïbes; L'aberration du Onzième Remède (1516). Ed. Victorien Lavou Zoungbo. Perpignan: Presses Universitaires de Perpignan, 2011.

Bennett, Herman L. Colonial Blackness: A History of Afro-Mexico. Bloomington: Indiana University Press, 2009.

Bennett, Herman L. African Kings and Black Slaves: Sovereignty and Dispossession in the Early Modern Atlantic. Philadelphia: University of Pennsylvania Press, 2018.

Brewer-García, Larissa. Beyond Babel: Translations of Blackness in Colonial Peru and New Granada. Cambridge: Cambridge University Press, 2020.

Brunstetter, Daniel. "Bartolomé de Las Casas." In Just War Thinkers: From Cicero to the 21st Century, ed. Daniel Brunstetter and Cian O’Driscoll, 92-104. London: Routledge, 2017.

Camplani, Clara. "La defensa de los Negros en Bartolomé de Las Casas." In Bartolomé de Las Casas (2011), 89-98.

Candido, Mariana P. "African Freedom Suits and Portuguese Vassal Status: Legal Mechanisms for Fighting Enslavement in Benguela, Angola, 1800-1830.” Slavery and Abolition 32.3 (2011): 447-59.

Candido, Mariana P. An African Slaving Port and the Atlantic World: Benguela and Its Hinterland. Cambridge: Cambridge University Press, 2013. 
Cañizares-Esguerra, Jorge. "Entangled Histories: Borderland Historiographies in New Clothes." American Historical Review 112.3 (2007): 787-99.

Cañizares-Esguerra, Jorge, ed. Entangled Empires: The Anglo-Iberian Atlantic, 1500-1830. Philadelphia: University of Pennsylvania Press, 2018.

Cárdenas, Eduardo. "La ética cristiana y la esclavitud de los negros: Elementos históricos para el planteamiento de un problema." Theologica Xaveriana 55 (April-June 1980): 227-57.

Castro, Daniel. Another Face of Empire: Bartolomé de Las Casas, Indigenous Rights, and Ecclesiastical Imperialism. Durham, NC: Duke University Press, 2007.

Chira, Adriana. "Affective Debts: Manumission by Grace and the Making of Gradual Emancipation Laws in Cuba, 1817-68." Law and History Review 36.1 (2018): 1-33.

Clayton, Lawrence A. Bartolomé de Las Casas: A Biography. Cambridge: Cambridge University Press, 2012.

Curto, José C. "The Story of Nbena, 1817-1820: Unlawful Enslavement and the Concept of 'Original Freedom' in Angola." In Trans-Atlantic Dimensions of Ethnicity in the African Diaspora, ed. Paul E. Lovejoy and David V. Trotman, 42-64. London: Continuum, 2003.

Curto, José C. "Struggling against Enslavement: The Case of José Manuel in Benguela, 181620.” Canadian Journal of African Studies 39.1 (2005): 96-122.

Curto, José C. "Experiences of Enslavement in West-Central Africa." Histoire sociale / Social history 41.82 (2008): 381-415.

Delmas, Adrien. "Introduction." In Written Culture in a Colonial Context: Africa and the Americas 1500-1900, ed. Adrien Delmas and Nigel Penn, xvii-xxxii. Leiden: Brill, 2012.

Dias Paes, Mariana Armond. "Shared Atlantic Legal Culture: The Case of a Freedom Suit in Benguela.” Atlantic Studies: Global Currents 17.3 (2020): 419-40.

Ferreira, Roquinaldo. Cross-Cultural Exchange in the Atlantic World: Angola and Brazil during the Era of the Slave Trade. Cambridge: Cambridge University Press, 2012.

Fromont, Cécile. The Art of Conversion: Christian Visual Culture in the Kingdom of Kongo. Chapel Hill: University of North Carolina Press, 2014.

Fuente, Alejandro de la. "Slave Law and Claims-Making in Cuba: The Tannenbaum Debate Revisited." Law and History Review 22.2 (2004): 339-69.

Fuente, Alejandro de la. Havana and the Atlantic in the Sixteenth Century. Chapel Hill: University of North Carolina Press, 2011.

Fuente, Alejandro de la, and Ariela J. Gross. Becoming Free, Becoming Black: Race, Freedom, and Law in Cuba, Virginia, and Louisiana. Cambridge: Cambridge University Press, 2020.

Garofalo, Leo J. "The Shape of a Diaspora: The Movement of Afro-Iberians to Colonial Spanish America." In Africans to Spanish America: Expanding the Diaspora, ed. Sherwin K. Bryant, Rachel Sarah O'Toole, and Ben Vinson III, 27-49. Urbana: University of Illinois Press, 2012.

Gaune Corradi, Rafael. Escritura y salvación: Cultura misionera jesuita en tiempos de Anganamón, siglo XVII. Santiago: Ediciones Universidad Alberto Hurtado, 2016.

Germeten, Nicole von. Violent Delights, Violent Ends: Sex, Race, and Honor in Colonial Cartagena de Indias. Albuquerque: University of New Mexico Press, 2013.

Gómez, Michael A. Black Crescent: African Muslims in the Americas. Cambridge: Cambridge University Press, 2005. 
Gómez, Pablo F. The Experiential Caribbean: Creating Knowledge and Healing in the Early Modern Atlantic. Chapel Hill: University of North Carolina Press, 2017.

González Sánchez, Carlos Alberto. Dineros de ventura: La varia fortuna de la emigración a Indias (siglos XVI-XVII). Seville: Universidad de Sevilla, 1995.

Gould, E. "Entangled Histories, Entangled Worlds: The English-Speaking Atlantic as a Spanish Periphery." American Historical Review 112.3 (2007): 764-86.

Green, Toby. The Rise of the Trans-Atlantic Slave Trade in Western Africa, 1300-1589. Cambridge: Cambridge University Press, 2012.

Green, Toby. "Beyond an Imperial Atlantic: Trajectories of Africans from Upper Guinea and West-Central Africa in the Early Atlantic World.” Past \& Present 230.1 (2016): 91-122.

Green, Toby. "Baculamento or Encomienda? Legal Pluralisms and the Contestation of Power in the Pan-Atlantic World of the Sixteenth and Seventeenth Centuries." Journal of Global Slavery 2.3 (2017): 310-36.

Green, Toby. "Pluralism, Violence and Empire: The Portuguese New Christians in the Atlantic World." In Cosmopolitanism in the Portuguese-Speaking World, ed. Francisco Bethencourt, 40-58. Leiden: Brill, 2018.

Green, Toby. A Fistful of Shells: West Africa from the Rise Slave Trade to the Age of Revolutions. London: Penguin, 2019.

Hanke, Lewis. All Mankind Is One: A Study of the Disputation between Bartolomé de Las Casas and Juan Ginés de Sepulveda in 1550 on the Intellectual and Religious Capacity of the American Indians. DeKalb: Northern Illinois University Press, 1994.

Havik, Philip J. "Walking the Tightrope: Female Agency, Religious Practice and the Portuguese Inquisition on the Upper Guinea Coast." In Bridging the Early Modern Atlantic World: People, Products and Practices on the Move, ed. Caroline A. Williams, 173-202. Farnham: Ashgate, 2009.

Havik, Philip J. “Gendering the Black Atlantic: Women's Agency in Coastal Trade Settlements in the Guinea Bissau Region." In Women in Port, Gendering Communities, Economies, and Social Networks in Atlantic Port Cities, 1500-1800, ed. Douglas Catterall and Jodi Campbell, 316-56. Leiden: Brill, 2012.

Herzog, Tamar. Defining Nations; Immigrants and Citizens in Early Modern Spain and Spanish America. New Haven, CT: Yale University Press, 2011.

Heywood, Linda M., and John K. Thornton. Central Africans, Atlantic Creoles, and the Foundation of the Americas, 1585-1660. Cambridge: Cambridge University Press, 2007.

Ireton, Chloe L. “'They Are Blacks of the Caste of Black Christians': Old Christian Black Blood in the Sixteenth- and Early Seventeenth-Century Iberian Atlantic." Hispanic American Historical Review 97.4 (2017): 579-612.

Jouve Martín, José R. Esclavos de la ciudad letrada: Esclavitud, escritura y colonialismo en Lima (1650-1700). Lima: Instituto de Estudios Peruanos, 2005.

Landers, Jane G. "The African Landscape of Seventeenth-Century Cartagena and Its Hinterlands." In The Black Urban Atlantic in the Age of the Slave Trade, ed. Jorge Cañizares-Esguerra, James Sidbury, and Matt D. Childs, 147-62. Philadelphia: University of Pennsylvania Press, 2013. 
Las Casas, Bartolomé de. Brevísima relación de la destrucción de África: preludio de la destrucción de Indias; primera defensa de los guanches y negros contra su esclavización. Ed. Isacio Pérez Fernández. Salamanca: Editorial San Esteban, 1989.

Latino, Juan. "The Song of John of Austria." In The Battle of Lepanto, ed. and trans. Elizabeth R. Wright, Sarah Spence, and Andrew Lemons, 288-405. Cambridge, MA: Harvard University Press, 2014.

Lofkrantz, Jennifer, and Olatunji Ojo. "Slavery, Freedom, and Failed Ransom Negotiations in West Africa, 1730-1900," Journal Of African History 53.1 (2012): 25-44.

Lucena Salmoral, Manuel, ed. Regulación de la esclavitud negra en las colonias de América Española (1503-1886): Documentos para su estudio. Alcalá: University of Alcalá de Henares, 2005.

Mangan, Jane E. Transatlantic Obligations: Creating the Bonds of Family in Conquest-Era Peru and Spain. Oxford: Oxford University Press, 2016.

Mark, Peter, and José da Silva Horta. The Forgotten Diaspora: Jewish Communities in West Africa and the Making of the Atlantic World. Cambridge: Cambridge University Press, 2011.

Martín Casares, Aurelia. Juan Latino: Talento y destino; Un afroespañol en tiempos de Carlos Vy Felipe II. Granada: Universidad de Granada, 2016.

Masters, Adrian. "A Thousand Invisible Architects: Vassals, the Petition-and-Response System, and the Creation of Spanish Imperial Caste Legislation." Hispanic American Historical Review 98.3 (2018): 377-406.

McKinley, Michelle A. Fractional Freedoms: Slavery, Intimacy, and Legal Mobilization in Colonial Lima, 1600-1700. Cambridge: Cambridge University Press, 2016.

McKnight, Kathryn J. “Confronted Rituals: Spanish Colonial and Angolan 'Maroon' Executions in Cartagena de Indias (1634).” Journal of Colonialism and Colonial History 5.3 (2004): 1-19.

Navarrete Peláez, María Cristina. Cimarrones y Palenques en el Siglo XVII. Cali: Universidad del Valle, 2003.

Navarrete Peláez, María Cristina. "Las cartas Annuas jesuitas: Y la representación de los etíopes en el siglo XVII." In Genealogias de la diferencia: Tecnologias de la salvación y representación de los africanos esclavizados en Iberoamérica colonial, ed. María Eugenia Chaves Maldonado, 22-57. Bogotá: Editorial de la Pontificia Universidad Javeriana, Instituto de Estudios Sociales y Culturales Pensar; Quito: Editorial Abya-Yala, 2009.

Navarrete Peláez, María Cristina. "El palenque de Limón (Cartagena de Indias, siglo XVII): El imaginario del poder y sus jerarquías." In Vicisitudes negro africanas en Iberoamérica: Experiencias de investigación, ed. Juan Manuel de la Serna Herrera, 101-34. Mexico City: Universidad Nacional Autónoma de México, Centro de Investigaciones sobre América Latina y el Caribe, 2011.

Navarrete Peláez, María Cristina. "Kings, Queens and Captains: Leaders of the Palenques of Sierras de María, during the XVI and XVII Centuries." Fronteras de la Historia 20.2 (2015): $44-62$.

Navarrete Peláez, María Cristina. "Consideraciones en Torno a la Esclavitud de los Etíopes y la operatividad de la Ley, Siglos XVI y XVII.” Historia y espacio 2.27 (2017): 1-23.

Newson, Linda A. "Africans and Luso-Africans in the Portuguese Slave Trade on the Upper Guinea Coast in the Early Seventeenth Century." Journal of African History 53.1 (2012): $1-24$. 
Newson, Linda A., and Susie Minchin. From Capture to Sale: The Portuguese Slave Trade to Spanish South America in the Early Seventeenth Century. Leiden: Brill, 2007.

Orique, David T. "A Comparison of Bartolomé de Las Casas and Fernão Oliveira: Just War and Slavery." E-Journal of Portuguese History 12.1 (2014): 87-118.

Orique, David T., and Rady Roldán-Figueroa, eds. Bartolomé de Las Casas, O.P.: History, Philosophy, and Theology in the Age of European Expansion. Leiden: Brill, 2018.

O’Toole, Rachel Sarah. Bound Lives: Africans, Indians, and the Making of Race in Colonial Peru. Pittsburgh, PA: University of Pittsburgh Press, 2012.

Pérez García, Rafael M., and Manuel F. Fernández Chaves. "La cuantificación de la población esclava en la Andalucía moderna: Una revisión metodológica.” Varia hist. 31.57 (2015): 711-40.

Pike, Ruth. "Sevillian Society in the Sixteenth Century: Slaves and Freedmen." Hispanic American Historical Review 47.3 (1967): 344-59.

Queija, Berta Ares. "La cuestión del bautismo de los negros en el siglo XVII: La proyección de un debate americano." In Mirando las dos orillas: intercambios mercantiles, sociales y culturales entre Andalucía y América, ed. Enriqueta Vila Vilar and Jaime J. Lacueva Muñoz, 469-85. Seville: Fundación Buenas Letras. http://hdl.handle.net/10261/57537.

Ramos, Gabriela, and Yanna Yannikakis, eds. Indigenous Intellectuals: Knowledge, Power, and Colonial Culture in Mexico and the Andes. Durham, NC: Duke University Press, 2014.

Rappaport, Joanne, and Tom Cummins. Beyond the Lettered City: Indigenous Literacies in the Andes. Durham, NC: Duke University Press, 2011.

Rowe, Erin Kathleen. Black Saints in Early Modern Global Catholicism. Cambridge: Cambridge University Press, 2019.

Sánchez-Godoy, Rubén A. "Bartolomé de Las Casas crítico de las esclavizaciones portuguesas en las islas Canarias y la costa occidental de África.” In Bartolomé de Las Casas (2011), 135-55.

Sánchez-Godoy, Rubén A. El peor de los remedios: Bartolomé de Las Casas y la critica temprana a la esclavitud africana en el Atlántico ibérico. Pittsburgh, PA: Instituto Internacional de Literatura Iberoamericana, 2016.

Sandoval, Alonso de. Naturaleza, policia sagrada i profana, costumbres i ritos, disciplina i catechismo evangelico de todos Etiopes, por el P. Alonso de Sandoval. Seville: F. de Lira, 1627. Bibliothèque nationale de France (BnF), Paris, département réserve des livres rares (LR), 4-O3C-6.

Sandoval, Alonso de. Treatise on Slavery: Selections from De Instauranda Aethiopum Salute. Ed. and trans. Nicole von Germeten. Indianapolis, IN: Hackett, 2008.

Sierra Silva, Pablo Miguel. Urban Slavery in Colonial Mexico: Puebla De Los Ángeles, 15311706. Cambridge: Cambridge University Press, 2018.

Silverblatt, Irene. Modern Inquisitions: Peru and the Colonial Origins of the Civilized World. Durham, NC: Duke University Press, 2004.

Splendiani, Anna María, José Enrique Sánchez Bohórquez, and Emma Cecilia Luque de Salazar, eds. Cincuenta años de inquisición en el Tribunal de Cartagena de Indias, 1610 1660. 4 vols. Bogotá: Pontificia Universidad Javeriana, 1997.

Splendiani, Anna María, and Tulio Aristizábal Giraldo, eds. Proceso de beatificación y canonización de san Pedro Claver. Bogotá: Pontifica Universidad Javeriana, 2002.

Tempère, Delphine. Vivre et mourir sur les navires du Siècle d'Or. Paris: Presses de l'Université Paris-Sorbonne, 2009. 
Thornton, John K. "The Development of an African Catholic Church in the Kingdom of Kongo, 1491-1750.” Journal of African History 25.2 (1984): 147-67.

Thornton, John K. "African Political Ethics and the Slave Trade: Central African Dimensions." In Abolitionism and Imperialism in Britain, Africa, and the Atlantic, ed. Derek R. Peterson, 38-62. Athens: Ohio University Press, 2010.

Thornton, John K. "Afro-Christian Syncretism in the Kingdom of Kongo." Journal of African History 54.1 (2013): 53-77.

Valenzuela, Jaime. “Revisitando el 'indigenismo' jesuita: En torno a los 'bárbaros' de Arauco, la guerra y la esclavitud mapuche en el siglo XVII." In Fronteiras e identidades: Encontros e desencontros entre povos indigenas e missóes religiosas, ed. Graciela Chamorro, Thiago Leandro Vieira Cavalcante, and Carlos Barros Gonçalves, 61-79. Sao Paulo: Nhanduti, 2011.

Van Deusen, Nancy. Global Indios: The Indigenous Struggle for Justice in Sixteenth-Century Spain. Durham, NC: Duke University Press, 2015.

Vidal Ortega, Antonino. Cartagena y la región histórica del Caribe: 1580-1640. Seville: Escuela de Estudios Hispanoamericanos, Universidad de Sevilla, and Diputación de Sevilla, 2002.

Vignaux, Hélène. L'Église et les Noirs dans l'audience du Nouveau Royaume de Grenade: Nueva edición [en línea]. Montpellier: Presses universitaires de la Méditerranée, 2009.

Wheat, David. "The First Great Waves: African Provenance Zones for the Transatlantic Slave Trade to Cartagena De Indias, 1570-1640." Journal of African History 52.1 (2011): 1-22.

Wheat, David. Atlantic Africa and the Spanish Caribbean, 1570-1640. Chapel Hill: University of North Carolina Press, 2016.

Wright, Elizabeth R. The Epic of Juan Latino: Dilemmas of Race and Religion in Renaissance Spain. Toronto: University of Toronto Press, 2016. 